\title{
Dysfunkcjonalizm metodologiczny - nowa propozycja analityczna w socjologii sportu i jej zastosowanie na przykładzie szachów
}

\author{
Jakub Ryszard Stempień \\ Uniwersytet Łódzki
}

DOI: http://dx.doi.org/10.18778/1733-8069.16.1.10

\author{
Słowa kluczowe: \\ sport, socjologia \\ sportu, \\ dysfunkcje sportu, \\ dysfunkcjonalizm \\ metodologiczny, \\ szachy
}

\begin{abstract}
Abstrakt: W artykule podejmowany jest problem operacjonalizacji definicji sportu, formułowanych na gruncie tak zwanego podejścia kontekstualnego i ustrukturyzowanego kontekstualizmu (typologia P. Nosala). Problematyczna jest bowiem kwestia, jak badać (kluczowe w tych definicjach) społeczne definiowanie danej praktyki jako sportowej. Zaproponowane autorskie rozwiązanie - nazywane dysfunkcjonalizmem metodologicznym - zakłada, że obserwowane w przypadku sportu negatywne zjawiska (dysfunkcje) mogą być traktowane jako wskaźniki określonego stanu świadomości społecznej. W analizie uwzględnia się pięć dysfunkcji, przyjmując Mertonowskie rozumienie tego terminu (z uszczegółowieniami Z. Bizonia i M. Sokołowskiej). Są to: doping, korupcja, polityzacja, komercjalizacja i mediatyzacja. Zaproponowane podejście jest następnie, w drugiej części artykułu, testowane w praktyce na przykładzie szachów. Wykorzystuje się tu definicję sportu zaproponowaną przez R. Giulianottiego. Zebrany materiał pokazuje, że w przypadku szachów można zaobserwować wiele z negatywnych zjawisk, które są „ciemnymi stronami” sportu w ogóle. Biorąc pod uwagę spełnienie wszystkich kryteriów definicyjnych Giulianottiego i potwierdzenie występowania typowo sportowych dysfunkcji, można - na gruncie dysfunkcjonalizmu metodologicznego - przyjąć, że obecnie szachy należy uznawać za sport.
\end{abstract}

Jakub Ryszard Stempień, socjolog sportu, adiunkt w Instytucie Socjologii Uniwersytetu Łódzkiego. Autor badań nad zjawiskiem mody na bieganie, przewodniczący jury Konkursu Sekcji Socjologii Sportu przy Polskim Towarzystwie Socjologicznym na najlepszą pracę licencjacką i magisterską z obszaru socjologii sportu.

\author{
Adres kontaktowy: \\ Katedra Socjologii Wsi i Miasta \\ Instytut Socjologii \\ Uniwersytet Łódzki \\ ul. Rewolucji 1905 r. nr 41, 90-214 Łódź \\ e-mail: j.r.stempien@wp.pl
}


port to zjawisko społeczne z wielu przyczyn niezwykłe. Uwagę zwraca już sama jego długa historia. Jak pisze Wojciech Lipoński (1987: 316), „najstarsze dowody istnienia form aktywności fizycznej zbliżonych do późniejszego sportu (rysunki naskalne, wykopaliska) pochodzą z epoki paleolitu młodszego (60-50 tys. p.n.e.)". W dzisiejszych czasach sport to biznes, rozrywka, hazard, argument w rywalizacji polityczno-gospodarczej między krajami, opcja tożsamościowa, wyznacznik pozycji społecznej jednostki i droga jej awansu społecznego, pretekst do burd i awantur w mniejszej lub większej skali (może nawet wojen), to także istotne zmiany w architekturze miast, pokusy oszustw na wielką skalę, siła napędowa dla badań naukowych w wielu dyscyplinach, pole testowania nowych technologii oraz podstawa dla moralnych i szerzej: filozoficznych rozważań o granicach człowieczeństwa. Taka heterogeniczność zjawiska prowadzi do dwóch konsekwencji. Po pierwsze, studiami nad różnymi aspektami sportu nie zajmują się wyłącznie specjaliści z zakresu nauk o kulturze fizycznej, ale też między innymi ekonomiści, psycholodzy, historycy, kulturoznawcy, filozofowie, pedagodzy i socjolodzy. Po drugie, wciąż występują pewne wątpliwości dotyczące istoty sportu. Wydaje się, że większość autorów byłaby skłonna zgodzić się, iż sport należy odróżnić od rekreacji ruchowej (wolnoczasowej, spontanicznej i niekoniecznie zorganizowanej aktywności fizycznej mającej cele zdrowotne, hobbystyczne i ludyczne) oraz ogółu kultury fizycznej (na którą, oprócz sportu, składać się będzie wspomniana rekreacja ruchowa oraz wychowanie fizyczne). Czym jednak jest sam sport?

Kwestia ta ma poważne znaczenie; żywa jest bowiem kontrowersja, czy takie dyscypliny rywalizacji intelektualnej, jak między innymi szachy, scrabble, warcaby (a od kilku dekad także: e-sport) należy uważać za sport, czy nie. Podobnie, czy takie „egzotyczne” konkurencje jako choćby szkocki rzut kłodą (caber toss) lub strzyżenie owiec to naprawdę sport? Na pytanie, czy są to dyscypliny sportowe (a dalej: czy mogłyby zostać włączone np. do programu igrzysk olimpijskich) odpowiadają naukowcy, działacze, dziennikarze i tak zwani zwykli ludzie. Muszą oni jednak opierać się na pewnej koncepcji dotyczącej istoty sportu i możliwości definiowania tego zjawiska.

Prezentowany artykuł został podzielony na dwie części. W pierwszej z nich przypomniane zostaną najważniejsze sposoby definiowania sportu, wraz ze wskazaniem ich słabości, w tym przede wszystkim trudności związanych z operacjonalizacją niektórych definicji. Zaproponowane będzie własne rozwiązanie $\mathrm{z}$ tego zakresu, nazywane dalej dysfunkcjonalizmem metodologicznym. Ta propozycja zostanie zastosowana w praktyce - w drugiej części tekstu - tak, aby udzielić odpowiedzi na pytanie, czy szachy są sportem.

\section{Dysfunkcjonalizm metodologiczny}

\section{Trzy perspektywy definicyjne}

Przemysław Nosal (2015) widzi trzy sposoby definiowania sportu. Opcja pierwsza to podejście atrybucyjne, polegające na wyliczeniu najważniejszych cech sportu. Można przyjąć, że jest ono właściwe dla reprezentantów nauk o kulturze fizycznej. Zbigniew Dziubiński (2003: 13-14), rekapitulując najczęstsze sposoby ujmowania istoty sportu, wymienia powtarzane w definicjach następujące cechy: dążenie do maksymalnych wyników, współzawodnictwo, ruchowy charakter aktywności, brak materialnego efektu, niezależność działania od motywów zwią- 
zanych z zaspokajaniem podstawowych potrzeb życiowych oraz wyzwalanie znacznych emocji. Dziubiński podkreśla zarazem, że kryteria niematerialności efektów i „szlachetności” motywacji nie odnoszą się do współczesnego sportu zawodowego. Podejście atrybucyjne jest reprezentowane między innymi przez klasyczne propozycje definicyjne opracowane przez Paula Weissa (1969 za: Krawczyk 2003: 162), Macieja Demela i Alicję Skład (1974: 18) oraz Wojciecha Lipońskiego (1987: 312).

Jak wspomniano wyżej, katalog cech definicyjnych sportu jest $\mathrm{w}$ poszczególnych definicjach atrybucyjnych podobny. Być może jedyna istotna różnica polega na tym, że niektórzy autorzy uwydatniają koniecznie ruchowy charakter aktywności sportowej (Demel i Skład, Lipoński, definicje analizowane przez Dziubińskiego), inni zaś ignorują te kwestie (Weiss), przyjmując, że zorganizowana, wymagająca przygotowań, ograniczona względnie niezmiennymi regułami, nieutylitarna rywalizacja intelektualna (jak w przypadku szachów czy brydża nomen omen sportowego) może zostać uznana za sportową.

Podejście atrybucyjne ma swoje mankamenty. Jak pisze Nosal (2015: 29), „słabość takiej strategii definicyjnej wiąże się z tym, że nie nadąża ona za zmieniającą się naturą rzeczywistości społecznej, a więc także samego sportu. Przyjęte kategorie opisu zjawiska stosunkowo szybko się bowiem dezaktualizują". Można by to chyba ująć również w sposób następujący. Strategia atrybucyjna daje możliwości rozstrzygania, co (np. jaki rodzaj aktywności, jaka dyscyplina) jest sportem, a co nie należy do sportowej domeny. Jest to podejście przydatne w przypadku funkcjonowania instytucji sportowych (jak choćby Międzynarodowy Komitet Olimpijski). Może mieć też zastosowanie w przypadku rozstrzy- gnięć prawnych ${ }^{1}$. Niemniej w dyskursie naukowym (ale i we wskazanym tu dyskursie instytucjonalnym) oznacza ono swoisty imperializm intelektualny. Dany autorytet (naukowiec, badacz, minister, urzędnik) orzeka, iż dana aktywność spełnia wyróżnione kryteria i z tej przyczyny powinna być uznawana za sport. Ignoruje przy tym aktualne społeczne wyobrażenia na temat tego, co jest sportem. Imperializm intelektualny to potencjalnie zarazem swoista ślepota, gdyż jako sportowe może zostać zdefiniowane to, co społecznie jako sportowe nie jest rozpoznawane, a tym samym nie ma społecznego znaczenia jako sport (prawdopodobnie nie będzie też $\mathrm{w}$ związku z tym pełnić społecznych funkcji przypisanych sportowi).

Od powyższego mankamentu wolna jest druga opcja definicyjna wskazana przez Nosala, a więc podejście kontekstualne. $\mathrm{W}$ tej perspektywie „sport pozostaje definiowany społecznie i to właśnie społeczeństwo - rozumiane jako specyficzny zbiorowy aktor - ma największą moc wyrażania jego obowiązującej natury kontekstowej, a szerzej - także klasyfikowania wszelkich zjawisk społecznych [...]

\footnotetext{
${ }^{1}$ W art. 2 pkt. 1. Ustawy z dnia 25 czerwca 2010 r. o sporcie (Dz. U. z 2017 r. poz. 1463) czytamy: „Sportem są wszelkie formy aktywności fizycznej, które przez uczestnictwo doraźne lub zorganizowane wpływają na wypracowanie lub poprawienie kondycji fizycznej i psychicznej, rozwój stosunków społecznych lub osiągnięcie wyników sportowych na wszelkich poziomach". W Ustawie z dnia 20 lipca 2017 r. wprowadzającej zmiany m.in. do ww. ustawy ustawodawca dodał zapis w postaci pkt. 1a, który głosi: „Za sport uważa się również współzawodnictwo oparte na aktywności intelektualnej, którego celem jest osiągnięcie wyniku sportowego". Tym samym m.in. szachy, brydż sportowy, scrabble, warcaby oraz cały obszar e-sportu powinny być obecnie, w świetle polskiego prawa, uznawane za przynależne do domeny sportowej. Podobnie wspomniany rzut kłodą i strzyżenie owiec spełniają prawnie wskazane kryteria aktywności sportowej. Z kolei w 2017 r. Trybunał Sprawiedliwości Unii Europejskiej orzekł, iż - z powodu braku komponentu wysiłku fizycznego - brydż nie może być uznany za dyscyplinę sportu. O orzeczenie w tej sprawie zwrócił się The English Bridge Union, licząc na objęcie zwolnieniem od podatku VAT (Brydż to nie sport? 2017).
} 
wszystko może być sportem, o ile tylko w dyskursie danej społeczności zostanie takim mianem określone" (Nosal 2015: 31-32)2. Nosal konstatuje, że opcja kontekstualna ma tę wadę, iż ostatecznie do zbioru aktywności sportowych należałoby włączyć wszelkie działania podejmowane „dla sportu” (siłowanie się na rękę itd.), mające $w$ istocie ze sportem niewiele wspólnego, ale czasem przez niektórych określane jako sport. Proponuje wobec tego rozwiązanie trzecie, mające charakter pośredni, nazywane przezeń ustrukturyzowanym kontekstualizmem. W tym autorskim podejściu Nosal pod pojęciem „sport” rozumie „zespół praktyk społecznych, które zbiorowości określają sportem, ale które posiadają również pewną utrwaloną i uniwersalną strukturę, definiowaną w określonej zbiorowości jako grupa fundamentalnych cech wspólnych, koniecznych, by coś określać mianem sportu" (2015: 33). Nosal wśród cech niezbywalnych sportu wskazuje: wyodrębnienie z szerszego kontekstu społecznego, konwencjonalność (podleganie regułom i kontroli), rywalizację, fakt realizowania działania sportowego przez ludzi i wobec innych ludzi oraz ruchowy charakter podejmowanej aktywności (2015: 34-36). Zatem sportem w tym ujęciu byłyby te zjawiska, które spełniają pięć wskazanych wyżej warunków i dodatkowo są społecznie uznawane za sport. Byłaby to propozycja zbliżona do stanowiska Richarda Giulianottiego (2005: xii-xiii), który - adaptując definicję Barry'ego McPhersona i współpracowników - twierdzi, iż aktywność sportowa posiada następujące właściwości: ustrukturowana (poprzez reguły i instytu-

\footnotetext{
${ }^{2}$ Wydaje się, że przykładu kontekstualnego ujmowania sportu dostarcza Dobiesław Dudek (brw), stwierdzając: „Pierwotnym wyznacznikiem sportu jest rywalizacja zwana po łacinie emulacją. W ogólnym znaczeniu proces powstawania zjawiska sportu polega więc na nadawaniu cechy rywalizacji dowolnej czynności ludzkiej, przy zachowaniu oczywiście jej standaryzacji. Stąd też każde zachowanie człowieka (utylitarne, militarne, towarzyskie, artystyczne, zabawowe itp.) może być uznane za sport lub też nie".
}

cje), zorientowana na cel, rywalizacyjna, zabawowa (ludyczna) oraz odpowiednio umiejscowiona i zakorzeniona w kontekście kulturowym (normatywnym, społecznym) (ang. culturally situated).

Problem, zarówno w przypadku podejścia kontekstualnego, jak i ustrukturyzowanego kontekstualizmu, polega na metodologicznej trudności stwierdzenia, czy dana praktyka jest społecznie uznawana za sport. Można bowiem postawić pytanie: skąd badacz sportu (np. socjolog) może o tym wnioskować? Oczywiście odpowiedź nie może odwoływać się do badań populacyjnych, gdyż od razu pojawia się kwestia wartości brzegowej: jak duży odsetek (tylko dorosłej? zgłaszającej zainteresowanie sportem?) zbiorowości i z jak silnym przeświadczeniem musiałby zadeklarować, że dana praktyka jest sportem, aby można było uznać, iż jest ona społecznie definiowana jako sport. Czy wystarczyłaby tu liczbowa przewaga potaknięć nad zaprzeczeniami (bez względu na odsetek odpowiedzi: „trudno powiedzieć"), czy też potrzebna byłaby jakaś kwalifikowana większość? Jak to orzec? Czy w analizie uznawać stanowiska liderów opinii (dziennikarzy sportowych, działaczy itd.)? Co począć w (prawdopodobnej lub wręcz nieuchronnej) sytuacji, gdy niektórzy ludzie uznają - szachy lub strzyżenie owiec - za sport, a inni odmówią im takiego uznania?

Podkreślić należy, że dylemat ten dotyka nie tylko opcji kontekstualnej, ale i perspektywy ustrukturyzowanego kontekstualizmu. Badacz może bowiem twierdzić, że (przykładowo) szachy lub brydż nie spełniają wyróżnionych kryteriów Nosala (brak komponentu aktywności fizycznej), lecz spełniają wszystkie kryteria Giulianottiego. Sprawę należy jednak domknąć poprzez odwołanie do kwestii, czy zbiorowość określa daną praktykę jako sport (Nosal) lub też, czy jest ona odpowiednio zakorzeniona 
w kontekście kulturowym (społecznym) (Giulianotti). Jak uporać się z tym zadaniem, przekładając ogólne kategorie definicyjne na terminy stosowne do potrzeb empirycznej weryfikacji? Jak zatem dokonać operacjonalizacji tych definicji?

Intencją prezentowanego artykułu jest przedstawienie pewnej propozycji rozwiązania powyższego dylematu. Otóż propozycja ta polegałaby na uznaniu, iż swoistym wskaźnikiem społecznego rozpoznawania danej aktywności jako sportowej będzie występowanie określonych negatywnych zjawisk właściwych sportowi. Jeśli zatem w przypadku szachów, e-sportu, scrabble lub rzutu kłodą można zaobserwować te fenomeny, które ogólnie nazywa się „ciemnymi stronami” sportu, to można uznać to za sui generis manifestację stanu świadomości społecznej, gdzie te aktywności są uznawane za dyscypliny sportowe.

\section{"Ciemne strony" sportu}

Wielu autorów wyraża zaniepokojenie kondycją współczesnego sportu. Problemom „ciemnych stron" sportu poświęcony został w 2009 roku numer specjalny periodyku „European Sport Management Quarterly". Redaktorka tego tomu, Andrea Petroczi, we Wprowadzeniu wskazała na rosnącą liczbę doniesień medialnych na temat dopingu, oszustw, przemocy na boisku i poza nim, a także korupcji w sporcie. Petroczi, nie bez zakłopotania, konstatowała przy tym, że zjawiska te współwystępują z doskonałością wyników uzyskiwanych przez zawodników (2009: 349; zob. też Schulenkorf, Frawley 2016).

Opierając się na powszechnie znanych faktach i przekazach medialnych, socjolodzy i etycy kreślą wizję sportu oddalającego się od ideałów bezintere- sownej i szlachetnej rywalizacji. Lipoński w następujący sposób pisze o zatraceniu idei olimpijskiej: „Coubertin i Brundage ${ }^{3}$ nie przewidzieli [...] gigantomanii igrzysk, ich powiązań ze światem ideologii i polityki, komercji i mediów. Duchowa dewastacja sportu niesiona przez te zjawiska ma dziś wiele wymiarów" (2009: 48). Jako dodatkowe niepokojące zjawiska w sporcie Lipoński wskazuje doping, nacjonalizm i "handlowanie” zawodnikami między klubami i krajami, odpowiedzialne za depersonalizację ciała ludzkiego (2009: 49; zob. też Dziubiński 2011a: 126-127).

Natomiast Zbigniew Krawczyk (2003: 165-166) wśród zagrożeń i deformacji sportu (szczególnie w XX stuleciu), dalej nazywanych przez niego plagami sportu, wymienia: nadmierną komercjalizację (której pochodnymi są gigantomania $\mathrm{w}$ zakresie organizacji imprez sportowych oraz korupcja), polityzację, chuligaństwo stadionowe, a także doping. Z kolei Jerzy Kosiewicz (2001: 189-195) wymienia następujące "patologie życia sportowego": doping farmakologiczny, korupcję i kaperownictwo (nieuczciwe, podyktowane nieetycznymi przesłankami pozyskiwanie młodzieży dla sportu), agresję kibiców oraz kryzys ideologii ruchu olimpijskiego. Na ten ostatni problem, według Kosiewicza, składa się kwestia zatracenia idei amatorstwa sportowego, a także (co może ważniejsze): polityzacja sportu, rasizm oraz nadmierna koncentracja na zarabianiu pieniędzy. Obserwacje innych autorów (Stańczuk 1995; Kowalczyk 2009: 54-55; Dziubiński 2011a; 2011b: 130-131; Leszczyńska 2013) stoją w zgodzie z powyższymi diagnozami.

\footnotetext{
${ }^{3}$ Pierre de Coubertin (1863-1937) jest uznawany za ojca nowożytnego ruchu olimpijskiego. Był założycielem i przewodniczącym Międzynarodowego Komitetu Olimpijskiego (MKOl). Avery Brundage (1887-1975) był działaczem sportowym; jako przewodniczący $\mathrm{MKOl}$ przeciwstawiał się komercjalizacji igrzysk oraz upolitycznieniu sportu.
} 
Podsumowując, do najczęściej wskazywanych „ciemnych stron” współczesnego sportu zaliczyć można następujące zjawiska, które będą rozpatrywane w dalszej analizie: 1) doping; 2) korupcja; 3) polityzacja sportu (wraz z jego powiązaniami ze sferą ideologii); 4) komercjalizacja; 5) mediatyzacja i widowiskowość wydarzeń sportowych (generujące dalsze zjawiska oceniane negatywnie); 6) gigantomania w zakresie organizacji imprez sportowych; 7) chuligaństwo stadionowe (i agresja kibiców).

\section{Patologie społeczne czy dysfunkcje?}

Warto postawić pytanie, czym $\mathrm{w}$ istocie są owe dość zróżnicowane - „plagi” i „,nieszczęścia” współczesnego sportu. Jaki jest ich socjologiczny status i sens? Mamy tu bowiem do czynienia ze zjawiskami penalizowanymi i takimi, które nie podlegają sankcjom instytucjonalnym. Rozpatrujemy fenomeny - jak można założyć - powszechnie (lub przynajmniej w obszarze kultury prawomocnej czy dominującej) uznawane za szkodliwe i wypaczające ideę sportowej rywalizacji oraz takie, które spotykają się nawet z pewną społeczną aprobatą (jak choćby widowiskowość czy skomercjalizowanie sportu). Uciekający od oględnego i niewiele mówiącego określenia „zjawiska negatywne” socjolog sportu może zwrócić się w stronę co najmniej dwóch naukowych terminów. Pierwszym będzie kategoria „patologii społecznej”, drugim - Mertonowskie pojęcie „dysfunkcji".

Irena Pospiszyl (2014: 12-13) relacjonuje, że „patologię społeczną definiuje się najczęściej jako negatywne zjawisko społeczne, które musi uwzględniać następujące warunki: 1) naruszanie norm i wartości; 2) destruktywność zachowania mierzona skalą potępienia społecznego; 3) występowanie w większej zbiorowości lub w skali masowej; 4) konieczność wykorzystania zbiorowej siły w celu przeciwstawienia się tego rodzaju problemom". Pospiszyl przypomina zarazem, że ludzie w odpowiedzi na patologie tworzą rozmaite zabezpieczenia, akty prawne oraz instytucje obrony.

Gdyby więc wypowiadać się o patologiach społecznych we współczesnym sporcie, to trzeba by w analizie uwzględnić jedynie te spośród enumerowanych jego „ciemnych stron”, które nie tylko są sprzeczne z normami i wartościami, ale też (ipso facto) generują społeczne potępienie, a w efekcie - działania zabezpieczające, śledcze, karne i tak dalej. Wymóg ten wydaje się być bezwzględnie spełniony w przypadku dopingu, korupcji oraz aktów chuligaństwa kibicowskiego, ale już nie w przypadku polityzacji, komercjalizacji, mediatyzacji czy organizacyjnej gigantomanii. Wszystkim tym zjawiskom zdaje się towarzyszyć jakaś społeczna przychylność albo przynajmniej ambiwalencja.

Przyjęcie za organizujący termin „patologia społeczna" istotnie zawęziłoby więc analizę, wykluczając z niej ważne zjawiska, które - w opinii ekspertów - wiążą się z upadkiem współczesnego sportu i stanowią zaprzeczenie jego podstawowych idei. Bardziej użyteczne będzie wobec tego pojęcie dysfunkcji, rozumiane za Robertem Mertonem (2002: 122) jako: „takie obserwowalne rezultaty, które pomniejszają adaptację czy modyfikację danego systemu". Aby rzecz była bardziej jednoznaczna, warto też przywołać następujące słowa Zdzisława Bizonia (1976: 107): „przez funkcjonalność rozumiemy to, że system realizuje te cele, do realizacji których został powołany. Są one określone (wyznaczone) przez nadrzędne potrzeby i wartości nadsystemu, w którego skład wchodzi dany system". Bizoń rozpatrywał kwestię dysfunkcjonalności systemu medycznego, funkcjonującego $\mathrm{w}$ ramach nadsystemu społecz- 
nego, czyli w ramach społeczeństwa i stwierdzał: „przez wiele wieków [...] system medyczny nie realizował tego, co było jego podstawowym celem, czyli był dysfunkcjonalny" (1976: 109)4 . Takie rozumienie funkcji, funkcjonalności, dysfunkcji i dysfunkcjonalności będzie stosowane w toku dalszego wywodu.

Przypomnijmy, że w swojej klasycznej analizie dysfunkcji organizacji biurokratycznych Merton (2002: 257 i nast.) rozpatrywał między innymi problemy wyuczonej nieudolności, psychozy zawodowej urzędników, nadmiernego konformizmu oraz przemieszczenia celów. W sposób widoczny dysfunkcje organizacji biurokratycznej - nie podlegając karom, będąc nawet $\mathrm{w}$ określonych sytuacjach wzmacniane przez zwierzchników - prowadzą do działań sprzecznych z jej celami, wypaczając jej funkcjonowanie. Dysfunkcje to zatem takie aktualne lub immanentne właściwości danego systemu społecznego (biurokracja, sport, system medyczny), które utrudniają realizację jego funkcji lub niweczą już uzyskane rezultaty.

Dla dalszych rozważań niezbędne będzie wskazanie, jakie są wobec tego funkcje sportu. Wykorzystując i syntetyzując dostępne w literaturze przedmiotu propozycje (Krawczyk 2000: 6-13; Waśkowski 2011: 27-29; Hajduk, Hajduk 2013: 9-11), można wskazać na następujące społeczne funkcje sportu wyczynowego:

1. wychowawcza i aksjonormatywna (kształtowanie i upowszechnianie odpowiednich wartości i wzorów postępowania, rozwój cech wolicjonal-

${ }^{4}$ Podobnie te kwestie rozumiała Magdalena Sokołowska (1972: 135), która stwierdzała, że dysfunkcjonalność to „zakłócenia w realizacji celów zakładanych instytucji, spowodowane realizacją innych celów niż zakładane". nych: determinacja w dążeniu do celu, dyscyplina, szacunek dla drugiego człowieka oraz zasad współżycia społecznego, kształtowanie postaw patriotycznych itd.);

2. zdrowotno-rozwojowa (promowanie aktywnego, zdrowego stylu życia, odpowiedni rozwój fizyczny jednostek);

3. rekreacyjno-integracyjna (pośrednia lub bezpośrednia konsumpcja sportowa, czyli kibicowanie, budowanie więzi między ludźmi w skali lokalnej, krajowej i międzynarodowej);

4. promocyjna (kształtowanie i umacnianie pozytywnego wizerunku przedsiębiorstw, organizacji, miast, regionów i krajów);

5. gospodarcza (generowanie zapotrzebowania na sprzęt i infrastrukturę sportową oraz popytu na usługi adresowane do sportowców i kibiców, ergo pomnażanie PKB, zwiększanie liczby miejsc pracy itd.);

6. naukowa (rozwój badań naukowych na potrzeby sportu, w tym w obszarze biologii, chemii, fizyki, psychologii, medycyny oraz nauk o kulturze fizycznej);

7. kulturotwórcza (kreacja i transmisja istotnych wartości, wpływ na twórczość artystyczną).

\section{Dysfunkcje współczesnego sportu}

Rozpatrzmy, czy wskazanych wyżej siedem najczęściej wymienianych „ciemnych stron” sportu można uznać za jego dysfunkcje, a więc za te jego właściwości, które osłabiałyby lub blokowały realizację przypisanych mu (także siedmiu) funkcji społecznych. 
Wydaje się jednoznaczne, że takie zjawiska jak korupcja $^{5}$ lub doping ${ }^{6}$ stanowią wyzwanie dla wielu z wyróżnionych funkcji sportu. Wypaczają one wyniki uzyskiwane przez zawodników, stojąc w oczywistej sprzeczności z wychowawczymi i rekreacyjnymi walorami sportu (dla widzów widowisko sportowe wydaje się mieć sens, jeśli wygrywa uczestnik najlepszy, najlepiej przygotowany, zaś obserwowane zmagania są rzeczywiste, nie zaś pozorowane czy „ustawione”). Wokół zawodów opartych na oszustwie trudno integrować jakąkolwiek zbiorowość kibiców (czy chcieliby identyfikować się ze sportowcami stosującymi doping lub sprzedającymi mecze?), a historia uczy, że afery dopingowe działają na sponsorów odstraszająco (Leszczyńska 2017: 21). Specjaliści z zakresu medycyny nie mają wątpliwości, że doping niszczy zdrowie i wypacza wzrost młodego organizmu (Manicka, Strzelecki 2010: 174-176), co stanowi zaprzeczenie zdrowotno-rozwojowej funkcji sportu. Z drugiej strony przyznać należy, że doping i korupcja mogą sprzyjać rozwojowi naukowemu (choćby $\mathrm{w}$ ramach doskonalenia możliwości ich wykrywania) oraz stymulować jakoś twórczość artystyczną (czego przykładem niech będzie głośny film pt. Piłkarski poker w reżyserii Janusza Zaorskiego). Trudno natomiast dostrzec istotny wpływ dopingu na gospodarcze funkcje sportu (brak logicznego związku). Niemniej uzasadnione jest przyjęcie (mało odkrywczego) ogólnego wniosku, iż doping i korupcja są w sporcie zjawiskami dysfunkcjonalnymi.

\footnotetext{
${ }^{5}$ Przez korupcję rozumie się tu wykorzystywanie posiadanej władzy publicznej czy pozycji zawodowej do uzyskania korzyści prywatnych (osobistych lub grupowych). Powiązane będą $\mathrm{z}$ tym m.in. nepotyzm, kumoterstwo, klientelizm oraz funkcjonowanie w sytuacji konfliktu interesów. (Kubiak 2013: 46).

${ }^{6}$ Doping jest tu rozumiany jako obecność zabronionej substancji w organizmie sportowca lub stosowanie zabronionej metody wraz z czynnościami przygotowawczymi i powiązanymi (Leszczyńska 2017: 12). Oprócz dopingu farmakologicznego rozróżnia się też doping genowy i technologiczny (Leszczyńska 2013: 52).
}

Rozważania o związkach polityki i sportu warto zacząć od kategorycznej tezy Dziubińskiego (2015: 27), iż „nie ma sportu bez polityki, poza polityka czy też sportu wyizolowanego od procesów i zjawisk społecznych oraz kulturowych, które zawsze [...] naznaczone są wpływami [...] polityki". Polityzacja sportu oczywiście może sprzyjać jego rozwojowi, jeśli wziąć pod uwagę finanse "płynące" z budżetu państwa do organizacji sportowych oraz rozmaite instytucjonalno-prawne ułatwienia dla sportu. Z drugiej strony podnoszone są argumenty, iż dla polityków sport jest zawsze tylko narzędziem, którym posługują się we własnych celach, niekoniecznie odpowiadających istocie samego sportu. Bywa więc sport używany propagandowo do wykazania wyższości pewnej opcji ideologicznej (niegdysiejsza olimpijska rywalizacja medalowa między krajami bloku wschodniego a państwami kapitalistycznymi) lub na potrzeby legitymizacji danego niedemokratycznego systemu i kraju (na arenie międzynarodowej lub w oczach obywateli) (Dziubiński 2015: 25 i nast.). Polityzacja może też sprzyjać państwowemu patronatowi nad dopingiem i sponsorowaniu tego procederu, czego przykładami niech będą ",sukcesy” sportowców Niemieckiej Republiki Demokratycznej czy - by odwołać się do faktów współczesnych - rosyjska afera dopingowa (Leszczyńska 2017: 21; Woźniak 2017: 152-155). Należy więc przyjąć, że - może niezbywalna, jak twierdzi Dziubiński - polityzacja i ideologizacja sportu stoją $\mathrm{w}$ opozycji przynajmniej wobec jego funkcji wychowawczych i integracyjnych, choć zarazem mogą wspierać funkcje rozwoju naukowego (finansowanie badań), promocji (kraju) oraz stymulacji twórczości artystycznej (jak choćby w przypadku filmu pt. Wielki bieg w reżyserii Jerzego Domaradzkiego czy zrealizowanej na państwowe zamówienie Olimpiady w reżyserii Leni Riefenstahl). Ze względu na wskazane aspek- 
ty negatywne polityzacja sportu będzie brana pod uwagę w dalszej analizie, jako zjawisko dysfunkcjonalne (choć mające też swoje znaczenie pozytywne z punktu widzenia funkcji sportu).

Kolejne zjawiska, których status należy tu rozpatrzeć, to komercjalizacja sportu oraz jego mediatyzacja. Komercjalizację, za Dominikiem Antonowiczem, Radosławem Kossakowskim i Tomaszem Szlendakiem (2011: 114), będzie się tu rozumieć jako „wystawienie na sprzedaż czegoś, co wcześniej niekoniecznie na sprzedaż było. Komercjalizacja to proces nakierowany na osiągnięcie zysku z dowolnego 'segmentu' życia społecznego czy kultury: jednostki, instytucji, organizacji, zachowań zbiorowych". W tym sensie oczywiście także sport (czy dokładniej: klub sportowy, zawodnik, a nawet prawo do organizacji określonej imprezy sportowej i prawo transmitowania jej przebiegu) będzie podlegać komercjalizacji. I tak, Krzysztof Jankowski (2011: 389) stwierdza, że „komercjalizacja kultury fizycznej znaczy tyle, co postrzeganie jej jako towaru mającego określoną wartość rynkową".

Niezwykle istotną rolę odgrywają tu media wraz z organizacjami sportowymi. Jak pisze Katarzyna Kopecka-Piech (2017: 77; zob. też Świerczyński 2017), „współczesny sport profesjonalny funkcjonuje dzięki popularności zawodników, dyscyplin czy wielkich imprez, a ona jest możliwa za sprawą transmisji, relacji, komentarzy itp. Między tymi dwoma ogniwami pośredniczą instytucje, które funkcjonują m.in. dzięki symbiozie mediów i sportu: organizacje, ligi, związki, stowarzyszenia itd. Często to one mają prawa do transmisji wydarzeń, które sprzedają stacjom telewizyjnym, czy też zawierają umowy ze sponsorami, którym gwarantują określoną widoczność w przekazie medialnym".
Można przyjąć, że mediatyzacja sportu powinna sprzyjać realizacji promocyjnej funkcji sportu. Przekonującą mogłaby być nawet teza, iż bez mediatyzacji spełnianie tej funkcji w ogóle nie byłoby możliwe. Widowiskowość sportu może wspierać funkcję integracyjną sportu (kreowanie globalnej publiczności sportowej czy wręcz globalnej wspólnoty kibiców) i - oczywiście - funkcję rekreacyjną (konsumpcja sportowa), zaś komercjalizacja sportu ściśle wiąże się z jego funkcjami gospodarczymi. Zatem rozpatrywane tu zjawiska byłyby nie tyle dysfunkcjonalne, co eufunkcjonalne właśnie!

Niemniej powyższe spekulacje trzeba uzupełnić o odpowiednie spostrzeżenia krytyczne. Przede wszystkim podważać można tezę, iż komercjalizacja sportu wspiera jego funkcję integracyjną. Specjaliści pokazują, że jest wręcz przeciwnie?. Co więcej, komercjalizacja sportu może też sprzyjać korupcji (kupowanie praw do organizacji imprez sportowych) (Leszczyńska 2013: 49). Jeśli przyjąć, że szczególnym przypadkiem komercjalizacji sportu będą zakłady bukmacherskie (a więc tzw. zakłady wzajemne dotyczące typowania wyników poszczególnych spotkań i rozgrywek sportowych), to pamiętać trzeba, że ta aktywność jest korupcjogenna, a rynkiem zakładów sportowych interesują się zorganizowane grupy przestępcze (Pawlak, Smoleń 2010: 108), co w sposób oczywisty odnosi się do dysfunkcjonalności w sporcie ${ }^{8}$. Mediatyzacja sportu ozna-

\footnotetext{
${ }^{7}$ Badacze tego zagadnienia twierdzą, że gra rynkowa „rozbija" wspólnotę integrującą kibiców na zindywidualizowanych konsumentów sportu, którzy tworzą jednorazową "grupę przynależnościową", funkcjonującą wyłącznie podczas widowiska sportowego (Antonowicz, Kossakowski, Szlendak 2011: 115).

8 Jakie jest znaczenie zakładów bukmacherskich (które są zdominowane przez zakłady dotyczące wydarzeń sportowych)? Otóż w 2015 r. w Polsce funkcjonowało 1995 punktów przyjmowania zakładów bukmacherskich; w sumie przychody legalnych bukmacherów wyniosły wówczas 1295825 tys. PLN, a udział zakładów wzajemnych w wartości całego
} 
cza z kolei w praktyce jego uzależnienie od mediów i podporządkowanie go ich wymogom. Chodzi tu między innymi o dostosowanie harmonogramu zawodów (w tym godzin rozgrywek sportowych) do grafiku potencjalnie największej oglądalności, a nawet o zmiany reguł rozgrywek, tak aby były bardziej „medialne” i zapewniały więcej czasu reklamodawcom (Świerczyński 2017: 202-205)9 . Traci na tym idea sportu.

Wszystko to podważa tezę o sprzyjaniu omawianych zjawisk funkcjom promocyjnym, gospodarczym i integracyjnym sportu lub przynajmniej czyni tę tezę bardzo kontrowersyjną. Bez wątpienia problematyczne pozostaja tu zagadnienia wychowawcze: jakie wartości są dziś "lansowane” przez sport, biorąc pod uwagę na przykład jego komercjalizację? Banalnym będzie wskazanie na absolutyzowanie pieniądza i jednoczesne relatywizowanie samego wyniku sportowego, który ma znaczenie, gdy może być spieniężony. Widowiskowość sportu i możliwość jego sprzedawania promują więc wartości odmienne od tych, których - w założeniu de Coubertina - sport miał być orędownikiem. Dlatego też komercjalizacja i mediatyzacja sportu mogą być uznawane za zjawiska

rynku hazardowego był równy 12,7\% (w porównaniu z 4,4\% z 2009 r., od tego czasu odnotowuje się systematyczne wzrosty) (Sobotko 2017: 97-98). Dodatkowo zaznaczyć trzeba, że są szacunki, wedle których w Polsce firmy bukmacherskie niemające zezwolenia na działalność gospodarczą na terenie kraju (chodzi tu przede wszystkim lub wręcz wyłącznie o e-hazard) już w 2013 r. posiadały ok. 91\% udziałów w rynku (Sobotko 2017: 100).

${ }^{9}$ Marek Jarosław Świerczyński (2017), analizując mediatyzację igrzysk olimpijskich, odwołuje się do przykładów zmian $\mathrm{w}$ regulaminie rozgrywek $\mathrm{w}$ piłce siatkowej (standaryzacja czasu, jaki trwają poszczególne mecze, pożądana z punktu widzenia konstruowania telewizyjnej ramówki), zmiany w regulaminie zawodów lekkoatletycznych (walka - poprzez dyskwalifikację - z falstartami psującymi widowisko sportowe i dekoncentrującymi kibiców), a także zmiany strojów zakładanych przez sportowców na takie, które są szczególnie atrakcyjne dla widza. dysfunkcjonalne w sporcie, choć - podobnie jak polityzacja - wydają się nieuchronne i mogą mieć też pewne znaczenie pozytywne.

Szczególnie atrakcyjne dla mediów (ale też widzów), sponsorów i organizacji sportowych (a więc z punktu widzenia możliwości spieniężenia widowiska sportowego) są tak zwane wielkie imprezy sportowe (ang. sports mega-events - SME), jak igrzyska olimpijskie czy mistrzostwa świata lub Europy w piłce nożnej. Jednak czy organizacyjną gigantomanię można uznać za dysfunkcję sportu? Badania pokazują, iż dziedzictwo (ang. legacy) i koszty organizacji SME są często niezadowalające. Składają się na to: na co dzień zbędne i puste (lecz drogie w utrzymaniu) gigantyczne stadiony (wybudowane specjalnie na potrzeby igrzysk, mundialu itp.), niedofinansowane pozasportowe dziedziny życia oraz łamane prawa najbiedniejszej ludności (wysiedlanej w związku z inwestycjami w obiekty sportowe i infrastrukturę transportową) (Włoch 2017: 247-249; zob. też Lenartowicz, Mosz 2018: 172 i nast.). Można więc organizacyjną hipertrofię uważać za zjawisko w sporcie niepożądane lub - dokładniej takie, wśród którego efektów są efekty negatywne z punktu widzenia idei sportu. Niemniej kluczowe jest, że trudno uważać organizacyjną gigantomanię za cechę całego sportu, a więc wszystkich dyscyplin sportowych. Przykłady tego zjawiska będą się - jak wspomniano - odnosić albo do piłki nożnej (mundial, mistrzostwa Europy), albo do igrzysk olimpijskich. W tym ostatnim przypadku chodzi zresztą raczej o całość sportowej imprezy (traktowanej jako pewien społeczny fenomen czy produkt) niż o przerosty organizacyjne, które bezpośrednio dotyczą poszczególnych dyscyplin. Prawdopodobne wydaje się raczej, że zawodnicy w takich konkurencjach jak choćby judo, pięciobój nowoczesny czy podnoszenie ciężarów (a ze sportów zimowych - łyżwiarstwo 
lub saneczkarstwo) na co dzień nie mają do czynienia z SME, a jedyną okazją jest udział w igrzyskach. Stąd organizacyjną gigantomanię trudno uznać za powszechną przypadłość sportu, z którą mają do czynienia zawodnicy we wszystkich dyscyplinach. Dlatego też nie zostanie ona włączona do dalszej analizy.

Podobnie przedstawia się sytuacja w przypadku ostatniej z wyróżnionych "plag” współczesnego sportu, a więc chuligaństwa stadionowego. Zapewne łatwo można by wykazać, że agresja kibiców stoi w sprzeczności z wychowawczymi ideałami (i funkcjami) sportu. Można też zasadnie dowodzić, że nie sprzyja jego funkcjom promocyjnym, gdyż zniechęca sponsorów i „zwykłych” kibiców (Gołata 2011). Stąd byłaby zjawiskiem dysfunkcjonalnym. Niemniej znaczenie kluczowe ma tu fakt, że chuligaństwo stadionowe pozostaje niemal wyłączną domeną tylko jednej dyscypliny sportowej, czyli - oczywiście - piłki nożnej (Dziubiński 2011a: $458)^{10}$. Można przytoczyć przykłady zachowań chuligańskich spotykanych w innych dyscyplinach Dziubiński (2011b: 459) pisze choćby o speedwayu - lecz będą to zapewne przykłady nieliczne. Co więcej, w niektórych sytuacjach może się okazać, że za „zadymami” towarzyszącymi innym niż piłkarskie imprezom sportowym stoją pseudokibice piłkarscy $(\text { sic })^{11}$. Chuligańskie wybryki kibiców, jeśli są choroba, to nie choruje na nią cały sport, lecz przede wszystkim futbol. W większości dyscyplin sportowych kibicowanie wiąże się z emocjami i afiliacją fanów, ale niekoniecznie przemocą (słowną czy fi-

\footnotetext{
${ }^{10}$ Znaczące jest, że socjolodzy sportu (w Polsce i za granicą) zajmujący się chuligaństwem stadionowym prowadzą studia właściwie tylko nad zachowaniami kibiców piłki nożnej (Kossakowski 2017: 47 i nast.).

${ }^{11}$ Przykładowo gala mieszanych sztuk walki (MMA) w Rzeszowie w 2011 r. została zakłócona przez kibiców Górnika Zabrze i GKS-u Katowice.
}

zyczną). Przykładem niech będzie piłka siatkowa (Woźniak 2011).

Podsumowując, socjologiczny status dysfunkcji można więc przypisać następującym pięciu bolączkom współczesnego sportu: 1) doping; 2) korupcja; 3) polityzacja (i ideologizacja); 4) komercjalizacja; 5) mediatyzacja.

\section{Wątpliwości}

Jak powinna zatem wyglądać analiza wykorzystująca zaproponowane tu podejście? Przede wszystkim badacz powinien wyjść od odpowiedniej definicji sportu, lokującej się $\mathrm{w}$ ramach opcji kontekstualnej (np. strategia Dudka) lub w ramach ustrukturyzowanego kontekstualizmu (perspektywa Nosala lub Giulianottiego). Stwierdziwszy spełnienie przez rozpatrywaną przez siebie aktywność (potencjalnie sportową) przyjętych kryteriów definicyjnych, powinien skierować swoją uwagę $\mathrm{w}$ stronę pięciu wskazanych wyżej dysfunkcji sportowych, poszukując odpowiedzi na pytanie, czy można je zaobserwować - w danym horyzoncie kulturowym - w odniesieniu do interesującej go aktywności. Przykład takiej analizy zostanie zaprezentowany $\mathrm{w}$ drugiej części niniejszego artykułu; najpierw należy jednak ustosunkować się do kilku wątpliwości, jakie skierować można pod adresem dysfunkcjonalizmu metodologicznego.

Po pierwsze, można postawić pytanie, dlaczego interesujące mają być dysfunkcjonalności sportu, nie zaś funkcje społeczne realizowane przez sport. Dlaczego więc socjolog sportu ma zajmować się raczej tym, co negatywne i spaczone, nie zaś tym, co pozytywne i twórcze? Otóż wydaje się, że to właśnie dysfunkcje wiążą się ze świadomymi, celowymi (czasem doraźnymi) działaniami podmiotów zbio- 
rowych lub jednostkowych, nie zaś funkcje (których występowanie socjolog może ewentualnie wykazać w swojej analizie i które mają charakter obiektywny, ale wattpliwe, czy koniecznie intencjonalny). W prezentowanym podejściu chodzi natomiast właśnie o kwestię społecznego rozpoznawania danej praktyki jako sportowej. A zatem, jeśli w odniesieniu do danej aktywności stwierdzić można przypadki stosowania dopingu i jeśli można mówić o jej polityzacji, komercjalizacji i tak dalej, to będzie to doskonałym wskaźnikiem społecznego rozpoznawania i uznawania tej aktywności jako dyscypliny sportu. Aktywność ta byłaby więc traktowana jak sport przez trenerów i zawodników próbujących oszukać sędziów, rywali i kibiców poprzez stosowanie dopingu (tak samo jest w kolarstwie, pływaniu itp.). Byłaby ona traktowana jak sport przez polityków wspierających jej rozwój oraz promujących mistrzów (postępujących zatem według identycznego modus operandi, jak w przypadku klasycznych dyscyplin sportowych). To samo można by też powiedzieć o reklamodawcach (czy bukmacherach), którzy uznawaliby, że na tej aktywności można zarobić w ten sam sposób, jak zarabia się na koszykówce czy piłce siatkowej.

Co natomiast począć z ewentualnym zarzutem dotyczącym historycznego charakteru dysfunkcji w sporcie? Zarzut ten w istocie opierałby się na dwóch przesłankach: po pierwsze, wszystkie obserwowane dziś „,ciemne strony” sportu nie są mu immanentnie przypisane; po drugie, w ogóle wątpliwe jest, aby dysfunkcjonalności jakiegoś systemu mogły utrzymywać się w długim okresie. Wszystko to ograniczałoby prawomocność proponowanej strategii analitycznej do „tu i teraz". Wobec przesłanki pierwszej (zgodnie z którą sport został pomyślany jako wolny od swoich obserwowanych dziś wypaczeń, niegdyś nie był nimi zbrukany i być może w przyszłości z nich się oczyści) należy stanowczo stwierdzić, że choroby współczesnego sportu nie są tak efemeryczne, jak można by sądzić. W sposób jednoznaczny wypowiada się w tej kwestii Dziubiński (2011b: 444), który pisze: „Śledząc wydarzenia sportowe doskonale widzimy, że niemal każdego dnia mają miejsce zachowania sportowców, trenerów, działaczy, właścicieli klubów, które naruszają standardy postępowania w sporcie, ale także w życiu społecznym. Ktoś uderzył przeciwnika na boisku, ktoś został przyłapany na stosowaniu niedozwolonych środków farmakologicznych, jacyś chuligani pobili sędziego i zdemolowali stadion, ktoś dokonał malwersacji klubowego mienia. Jeśli nawet potępiamy tego rodzaju zachowania, to musimy sobie zdać sprawę z tego, że są one nie do uniknięcia, że ich obecność jest niejako wpisana we współczesny sport. Nie możemy też liczyć na radykalne zmniejszenie się ilości zachowań dewiacyjnych czy przestępczych. Jeśli jednak zrozumiemy przyczyny ich występowania, to być może uda się nam wspólnym wysiłkiem ograniczyć tempo ich narastania". Warto tu odwołać się również do argumentacji Ewy Kałamackiej (2000: 151-157; zob. też Jankowski 2011: 387-388), która w interesujący sposób wywodzi, że wiele z krytykowanych atrybutów sportu XX wieku (rekordyzm, merkantylizm, zawodowstwo i doping) w istocie cechowało też sport olimpijski w starożytnej Grecji. Dodajmy ponadto, że liczne negatywne zjawiska współcześnie kojarzone ze sportem „przykleiły” się do igrzysk olimpijskich od właściwie początku ich nowożytnych dziejów. Jak przypomina Maciej Łuczak (2018: 120), „Pierwszych oficjalnych obserwacji stosowania dopingu u ludzi dokonano na Igrzyskach Olimpijskich w Los Angeles w 1932 r., gdy w kwaterze japońskich pływaków, zdobywców kilku medali olimpijskich, znaleziono ampułki zawierające m.in. mieszaninę, w skład której wchodziła także nitrogliceryna". Wcześniej (1912 r.) 
przypadki stosowania dopingu podczas wyścigów konnych dokumentował polski farmaceuta Alfons Bukowski (Łuczak 2018). Pamiętajmy, że już de Coubertin nawoływał: „mniej rozgłosu, mniej reklam, mniej biurokratycznych organizacji, nietolerancyjnych stowarzyszeń i ociężałych struktur!" (1989: 405 za: Lipoński 2009: 49).

Jeśli zaś chodzi o przesłankę drugą (wskazującą na wyłącznie przejściowy charakter dysfunkcjonalności danego systemu), to warto tu ponownie przywołać analizy Bizonia (1976) dotyczące dysfunkcji systemu medycznego, mających wielowiekową ",tradycję" (pozory leczenia, wobec niedostatków wiedzy medycznej) i według tego wybitnego psychiatry utrzymujących się (choć $\mathrm{w}$ zmienionej postaci wobec wzrostu skuteczności terapii w medycynie) także w drugiej połowie XX wieku. Podobnie uporczywe trwanie cechuje inne dysfunkcje medycyny, o których przeszło 40 lat temu pisała Sokołowska (1972) (nadmierna specjalizacja w obrębie profesji lekarskich, zbyt małe znaczenie lekarzy rodzinnych). To samo można powiedzieć o klasycznej Mertonowskiej analizie dysfunkcji biurokracji. A zatem określone systemy mogą trwać (przynosząc korzyść jednostkom i grupom najsprawniej w ich obszarze zabiegającym o własne interesy), pomimo właściwych im dysfunkcjonalności. Dysfunkcjonalności te (nierzadko ukrywane) mogą być wręcz zrośnięte z tymi systemami, pomimo rozmaitych działań nakierowanych na ich zwalczanie.

Pod adresem dysfunkcjonalizmu metodologicznego można sformułować jeszcze następującą obiekcję. Otóż wykorzystuje się tu w analizie pewne fenomeny (dysfunkcje), które co prawda są właściwe sportowi, ale nie są jego cechami szczególnymi. Sport ulega zatem mediatyzacji, komercjalizacji, polityzacji i tak dalej, ale tym samym negatywnym zjawiskom ulegają i inne obszary życia społecznego. Można więc mówić przykładowo o komercjalizacji systemu medycznego i zdrowia, o ideologizacji oświaty oraz o korupcji w polityce. Być może jedynie doping byłby dysfunkcją wyłącznie sportową. Czy wykorzystywanie pakietu tych dysfunkcji $\mathrm{w}$ analizie socjo-sportowej ma zatem sens? Odpowiedź będzie następująca. Każda z tych dysfunkcji ma, w przypadku sportu, swoją specyficzną, wyróżniającą formę. Korupcja w sporcie polega na przykład na przekupieniu sędziego (,wydrukowanie wyniku spotkania”) lub przekupieniu funkcjonariuszy organizacji sportowej, przyznającej prawo organizacji danej imprezy. Komercjalizacja w sporcie to choćby „handel” zawodnikami lub zakłady bukmacherskie. Podobnie przedstawia się sytuacja w przypadku innych wyróżnionych dysfunkcji. A zatem zaobserwowanie dysfunkcji, w ich typowo sportowych postaciach (niespotykanych na innych polach), można traktować jako wskaźnik społecznego rozpoznawania danego obszaru (dyscypliny) jako właśnie sportowego.

Wątpliwość ostatnia dotyczyć może uniwersalności zaproponowanego tu podejścia. Czy byłoby ono przydatne także $\mathrm{w}$ analizach systemów innych niż sport? Na myśl przychodzą choćby wspomniany wyżej system medyczny, oświata i polityka. Oczywiście nietrudno o odpowiednio udokumentowane przykłady rozmaitych dysfunkcji w tych polach. Niemniej, w odniesieniu do wskazanych obszarów działania zbiorowego, świadomość społeczna nie wydaje się być kryterium definicyjnym, tak jak w przypadku sportu. Gdyby jednak wykazać, że medycyną (oświatą, polityką itd.) jest ta domena działalności zbiorowej, która - oprócz spełnienia ewentualnych warunków wstępnych - jest społecznie rozpoznawana jako medycyna (oświata, polityka), to można by oczywiście pokusić się o za- 
stosowanie także w tym przypadku strategii dysfunkcjonalizmu metodologicznego. Ambicje autora są jednak skromniejsze i przyjmuje on, że omawiane podejście może być użyteczne chyba tylko na gruncie socjologii sportu.

\section{Czy szachy to sport?}

Gra w szachy zawsze była i będzie przyjemna rozrywka dla człowieka, bez względu na jego wiek. Oddajmy jej więc należna chwatę i podziękowanie. Jest ona królowa wszystkich gier. Walka szachowych figur nie jest obliczona na zysk, jest to walka honorowa. Szachy sa gra filozofów. Zapoznajcie z nia możnych tego świata, a przekonacie się, iż zmniejszy się ilość zła, a zatriumfuje moralność i piękno.

Paul Morphy (1837-1884)

Szachy niestety przestały być przede wszystkim sztuka, a stały się sportowa fabryka z dużymi pieniędzmi. [...] Za reklamę napojów Schweppes zapłacono mistrzowi świata póttora miliona dolarów. Kasparow miał tylko powiedzieć, że przed partia wypija buteleczkę Schweppesa. Kto go tam wie, czy wypija, ale za takie pieniadze każdy by to powiedziat. Miguel Najdorf (1910-1997)

\section{Sportowa historia i infrastruktura szachów}

Szachy są grą bardzo starą; najprawdopodobniej narodziły się w latach 70. VI wieku naszej ery w Indiach (były wówczas znane pod nazwą chaturanga) (Giżycki 1984: 11; 51 i nast.). Szachy szybko dotarły do Europy, stając się lubianą i cenioną formą rozrywki na całym kontynencie; ich patronem był zmarły w 814 roku Karol Wielki (Giżycki 1984: 16). Także w Polsce szachy znane są od dawna, o czym świadczy między innymi niemal pełen komplet tak zwanych szachów sandomierskich, datowanych na przełom XI i XII wieku (Giżycki 1984: 33). Odpowia- da to tradycyjnemu poglądowi, zgodnie z którym szachy mieli ze sobą przywieźć na ziemie polskie rycerze wracający z wypraw krzyżowych za czasów Bolesława Krzywoustego (Giżycki 1984: 29). Złoty okres szachów w Europie nastąpił w epoce Odrodzenia. Najlepszymi szachistami byli wówczas gracze z Włoch i Hiszpanii (Paolo Boi, Greco-Kalabryjczyk, Ruy Lopez, Alessandro Salvio i inni), a niektóre z rozegranych przez nich partii są znane do dziś (Gawlikowski 1976: 16-20; Litmanowicz, Giżycki 1986: 353). Odrodzenie to, za sprawą królowej Bony, czas wzrostu popularności szachów także w Polsce, które „stały się grą reprezentacyjną w salonach pałacowych i ulubioną rozrywką polskich humanistów" (Giżycki 1984: 35). Warto pamiętać, że Jan Kochanowski poświęcił tej grze poemat $S z a-$ chy, wzorując się na włoskim dziele Marca Girolamo Vidy pod tytułem Scacchia ludus.

Pierwszy międzynarodowy turniej szachowy został rozegrany w 1851 roku w Londynie. Jego zwycięzca, profesor matematyki we wrocławskim gimnazjum, Adolf Anderssen, był przez wielu uważany za najlepszego szachistę świata (Gawlikowski 1976: 36-37; Litmanowicz, Giżycki 1986: 34-35), lecz z czasem (1858 r.) uległ Amerykaninowi Paulowi Morphy'emu. Pierwszym powszechnie uznawanym mistrzem świata był Wilhelm Steinitz, choć dyskusyjne jest, czy za mecz o mistrzostwo należy uznać jego zwycięskie starcie z Anderssenem z 1866 roku (Giżycki 1984: 43), czy z Johannesem Zukertortem z 1886 roku (Gawlikowski 1976: 51 i nast.). W 1924 roku utworzona została Międzynarodowa Federacja Szachowa (fr. Fédération Internationale des Échecs - FIDE), do dziś organizująca olimpiady szachowe i rozgrywki o indywidualne mistrzostwo świata, a także odpowiadająca za określenie oraz interpretowanie reguł gry w szachy i przyznająca tytuły szachistom (mistrz, arcymistrz) i sędziom szachowym. 
Co szczególnie ważne z punktu widzenia dalszych rozważań, zmaganiom szachowym właściwie od zawsze towarzyszyła idea wyłaniania najlepszych graczy. Jak przypomina Jerzy Giżycki (1984: 15-16), w świecie arabskim rozgrywano mecze i turnieje szachowe już w VIII wieku naszej ery (sic). Nie były więc szachy chyba nigdy grą (jak choćby wiele gier karcianych), której ludyczny sens wyczerpywałby się w danej, konkretnej rozgrywce między uczestnikami. Idea rywalizacji sportowej i samego mistrzostwa wydaje się być do szachów nieodmiennie przywiązana. Dziś mecze o mistrzostwo świata w szachach są ważną, cykliczną imprezą sportową, przykuwającą uwagę miłośników królewskiej gry z całego świata.

Szachy mają swoją "sportową infrastrukturę" nie tylko w skali globalnej, ale i w skali krajowej czy wręcz lokalnej (okręgowej). Główny Urząd Statystyczny informuje, że w Polsce w 2016 roku w 458 sekcjach sportowych trenowało szachy 18807 osób (Cierpiał-Wolan, Łysoń 2017: 28, 79). Szachiści grali w ramach Akademickiego Związku Sportowego (309 osób), Zrzeszenia „Ludowe Zespoły Sportowe” (1 615 osób), Szkolnych Związków Sportowych (59 osób), Uczniowskich Klubów Sportowych (8 686 osób), klubów wyznaniowych (50 osób) oraz w ramach innych form organizacyjnych (8 088 osób) (Cierpiał-Wolan, Łysoń 2017: 26). W 2016 roku było w Polsce 148 trenerów szachowych, 536 instruktorów oraz 225 innych osób prowadzących zajęcia w omawianej dyscyplinie (Cierpiał-Wolan, Łysoń 2017: 119). W Polskim Związku Szachowym w 2016 roku było 1020 sędziów sportowych, w tym 70 z klasą międzynarodową (Cierpiał-Wolan, Łysoń 2017: 148). Kadra narodowa PZSzach liczyła wówczas 172 osoby (Cierpiał-Wolan, Łysoń 2017: 130).

Z drugiej strony szachiści niekoniecznie z wyglądu muszą przypominać "typowych” idoli sportowych, a i rozgrywki szachowe - choćby ze względu na niespecyficzny ubiór zawodników oraz niespecyficzny charakter miejsca zawodów (hale widowiskowe, sale koncertowe, sceny teatrów, hotelowe sale konferencyjne itd.) - nie są podobne do zawodów w takich dyscyplinach jak lekkoatletyka, piłka nożna, wyścigi konne lub rajdy samochodowe. Są więc szachy sportem?

\section{Szachy, aktywność ruchowa, istota sportu}

Problem, czy szachy należy uznawać za sport, jest co pewien czas stawiany w debacie naukowej. Podstawową kwestią jest brak komponentu aktywności fizycznej w przypadku tej dyscypliny. Jeśli więc badacz przyjmuje taką definicję sportu, która jako niezbędny warunek wskazuje właśnie na aktywność ruchową (np. Demel, Skład 1974; Lipoński 1987; Nosal 2015; Coakley 2001 za: Kobiela 2018; Suits 2007 za: Kobiela 2018), to powinien uznać, że szachy nie są sportem. I odwrotnie, jeśli będzie wykorzystywać taką definicję sportu, która ignoruje kwestie aktywności fizycznej (np. Weiss 1969; Giulianotii 2005; Dudek brw), to może - przy spełnieniu pozostałych kryteriów danej definicji - dowodzić, iż szachy należy uznawać za dyscyplinę sportową.

Próby argumentowania, iż także w przypadku szachów możliwe jest wskazanie komponentu ruchowego należy uznać za raczej naiwne, niewiele wnoszące lub wręcz sofistyczne ${ }^{12}$. I tak, przykładowo,

\footnotetext{
${ }^{12}$ Filip Kobiela (2018: 282-285), odnosząc się do realiów gry turniejowej, wskazuje, że skrajna niesprawność (np. paraliż) umożliwiałaby danemu zawodnikowi udział wyłącznie w rozgrywkach korespondencyjnych, zaś z drugiej strony tzw. szachy błyskawiczne (w przypadku których czas pozostający do dyspozycji zawodnika na całą partię wynosi 5 minut lub krócej) wymagają precyzji i sprawności. Te argumenty konfirmowałyby niezbędność sprawności fizycznej szachistów z punktu widzenia rozgrywki. Kobiela przyznaje jednak, że $\mathrm{w}$ istocie $\mathrm{w}$ szachach chodzi o sprawność umysłową, a nie fizyczną, która ma w tym wypadku status wyłącznie instru-
} 
Jacek Gajewski (2012: 9) pisze, że przecież „miłośnik królewskiej gry [...] osobiście podejmuje ruchowy charakter działania z akcentem specjalistycznym". Zwróćmy tu uwagę na abstrakcyjny charakter ruchu szachowego, którego istota jest przecież niematerialna (partie można rozgrywać w pamięci), a figury i szachownica są tu jedynie pewnymi dodatkowymi, ułatwiającymi grę materializacjami. W tym sensie ruchu szachisty nie można porównywać do, skądinąd oszczędnego, ruchu łucznika czy kierowcy rajdowego. W interesujący sposób kwestie te, na kanwie koncepcji Romana Ingardena, dyskutuje Filip Kobiela (2015).

Zdaniem Kobieli (2018) naukowi rzecznicy sportowej tożsamości szachów powinni - zamiast roztrząsać fizyczne aspekty rozgrywki szachowej - skupić się raczej na podważeniu tezy o koniecznie ruchowym charakterze aktywności sportowej i tym samym odrzucić druga przesłankę tak zwanego sylogizmu sportów umysłowych. Argumentować tu można, że podobnie jak nie wszystkie uznane dyscypliny sportu są grami (np. pływanie synchroniczne), tak i nie wszystkie muszą wiązać się z rywalizacją fizyczną. Kobiela (2018: 291-293) podkreśla przy tym historyczny charakter sportu, wskazując, że temu, co dziś w sposób niekontrowersyjny jest zaliczane do sportowej domeny (choćby badminton), jeszcze do niedawna można było odmawiać sportowej (choćby olimpijskiej) etykiety. Kilka przesłanek pozwala przewidywać, iż w nadchodzącym czasie sporty umysłowe (a więc i szachy) zostaną uznane za dyscypliny sportowe. Przede wszystkim wskazać tu można na swoistą akulturację terminu „sport umysłowy" (ang. mind sports), co będzie legitymizować uznanie dyscyplin rywalizacji intelektualnej

mentalny. Nawet jednak przyjęcie powyższej argumentacji nie wpływałoby na niesportowy status klasycznych szachów turniejowych (z rozgrywkami kilkugodzinnymi). za dyscypliny sportowe. Dodać do tego należy integrację sportów umysłowych, wzrastające znaczenie e-sportu, pojawianie się nowych dyscyplin sportowych włączających dyscypliny umysłowe (vide: szachoboks) oraz rosnące znaczenie różnych tradycji w definiowaniu sportu (Kobiela 2018: 292).

Niemniej rozważania Kobieli funkcjonują na - tutaj mniej zajmującym - gruncie atrybucyjnym. Kobiela przyjmuje, że społeczne rozumienie sportu jest zmienne (zależne od czasu i kultury) i że ma to istotne znaczenie dla filozofów czy socjologów sportu. Znaczenie to powinno jednak manifestować się w aktualizowaniu poszczególnych ujęć sportu. Tak więc - wedle Kobieli - konkretne definicje atrybucyjne powinny się zmieniać, dostosowując swoją treść do aktualnych społecznych wyobrażeń na temat istoty sportu. Jest to inne postawienie sprawy niż w przypadku strategii kontekstualnej lub ustrukturyzowanego kontekstualizmu, gdzie społeczne definiowanie sportowego fenomenu jest wpisane w samą treść definicji.

Prezentowana dalej analiza będzie więc stanowić przykład możliwego zastosowania dysfunkcjonalizmu metodologicznego, opierając się na definicji Giulianottiego. Poszczególne kryteria tej definicji są w przypadku szachów spełnione. Aktywność ta ma bowiem charakter ustrukturyzowany (reguły gry są skodyfikowane, znane zawodnikom, a nad ich przestrzeganiem każdorazowo czuwa sędzia danej imprezy; zawody podlegają rygorom PZSzach i FIDE). Cel rozgrywki jest jednoznaczny (zamatowanie przeciwnika lub doprowadzenie do takiej sytuacji na szachownicy, która skłoni rywala do poddania partii wobec braku szans na wygraną lub remis) i ma charakter rywalizacyjny właśnie (rozgrywki są grą o sumie zerowej: jedna osoba przegrywa, druga zostaje zwycięzcą; nawet jeśli 
w danej partii uzgodniony zostanie remis, to partia ta jest elementem turnieju lub meczu, a on ma już charakter rezultatywny). Całość rozgrywek można uznać za zabawową z kilku względów. Po pierwsze, służą one rozrywce kibiców. Po drugie, w wersji amatorskiej - gra w szachy służy rozrywce graczy. Po trzecie, nawet rozpatrując grę profesjonalną, przyznać trzeba, że wyrasta ona z rozgrywek amatorskich i wolnoczasowych, stricte rekreacyjnych. Otwarta pozostaje jedynie kwestia umiejscowienia i zakorzenienia rozgrywek szachowych w kontekście kulturowym (normatywnym, społecznym). Czy można zatem mówić o społecznym rozpoznawaniu szachów jako dyscypliny sportowej? Czy w przypadku szachów zaobserwować można typowo sportowe dysfunkcje, co byłoby tu wskaźnikiem określonego stanu świadomości społecznej? Odpowiedzi na te pytania powinna dostarczyć poniższa analiza, z tym zastrzeżeniem, że jest ona zawężona do określonego horyzontu kulturowego (krąg euro-amerykański doby postprzemysłowej).

\section{Sportowe "ciemne strony" szachów, czyli dysfunkcjonalizm metodologiczny $w$ praktyce}

Poniżej rozważonych zostanie kolejno pięć dysfunkcji sportowych (doping, korupcja, polityzacja, mediatyzacja, komercjalizacja) pod katem ich obecności w przypadku rozgrywek szachowych.

A zatem, czy w szachach można stosować substancje dopingujące, zwiększające sprawność umysłową (np. koncentracja, szybkość i głębia obliczeń)? Kontrole antydopingowe faktycznie są przeprowadzane, jednak dostępne substancje pobudzające czy stymulujące okazują się $\mathrm{w}$ przypadku wysił$\mathrm{ku}$, jakim jest namysł szachowy, mało skuteczne. Tak zwane leki wzmocnienia poznawczego (ang. cognitive-enhancing drugs, cognitive enhancers - CE) oddziałują pozytywnie tylko na osoby funkcjonujące na niskim poziomie sprawności umysłowej i z punktu widzenia szybko przeliczających i wyćwiczonych $\mathrm{w}$ abstrakcyjnym myśleniu szachistów są nieprzydatne (Golf 2015; Mihailov, Savulescu 2018). Ostatnio wykryto, że dwie substancje (Modafinil i Metylofenidat, znany też pod nazwą Ritalin) mogą nieco poprawiać grę szachistów ${ }^{13}$, lecz ich stosowanie wiązałoby się zarazem $\mathrm{z}$ wydłużeniem czasu niezbędnego do namysłu (a ten jest limitowany i kontrolowany za pomocą specjalnych zegarów) (Franke i in. 2017). Poważniejszym niż doping farmakologiczny problemem w przypadku szachów jest doping technologiczny, opierający się na nieuczciwym i potajemnym (za pomocą kamerek, słuchawek, a nawet smarftonów ukrywanych w... toalecie) użyciu szachowych programów komputerowych i korzystaniu z ich podpowiedzi podczas gry (nierzadko przy wsparciu wspólnika) (Prost 2012). Są udokumentowane przypadki takich praktyk, mających miejsce także w rozgrywkach na najwyższym, światowym poziomie (Prost 2012).

Jeśli natomiast chodzi o korupcję $\mathrm{w}$ szachach, to $\mathrm{w}$ raporcie Zjawisko korupcji w środowisku sportowym. Analiza w oparciu o badania empiryczne (Openfield 2018: 22-23, 32-33), opracowanym na zlecenie Ministerstwa Sportu i Turystyki, czytamy, że respondenci profesjonalnie (wyczynowo) trenujący szachy przyznawali (co trzeci), iż spotkali się osobiście z przypadkiem korupcji, oceniając zarazem, że $\mathrm{w}$ szachach istnieje mniejsze niż $\mathrm{w}$ innych sportach zagrożenie zachowaniami korupcyjnymi. Z kolei $\mathrm{w}$ raporcie Protecting the Integrity of Sport Competition (ICSS 2014: 76), przygotowanym na Uniwersyte-

${ }^{13}$ Wskazywano, że rozmiary przewagi uzyskiwanej dzięki stosowaniu tych substancji mogłyby być przyrównywane do uprzywilejowania wynikającego z gry kolorem białym, nie zaś czarnym. 
cie Paryskiem (Sorbona), szachy są zaliczane (obok m.in. sportów lotniczych, warcabów, fistballu, wspinaczki oraz wyścigów psich zaprzęgów) do grona dyscyplin o bardzo niskim ryzyku manipulacji wynikami $^{14}$. Autorzy raportu podkreślają zarazem, że w przypadku szachów występuje jednoznaczne i klarowne odniesienie do etyki sportowej i kwestii manipulacji w oficjalnych dokumentach właściwej międzynarodowej federacji sportowej (FIDE) (ICSS 2014: 77). Wszystko to zdaje się wskazywać, że przypadki korupcji w szachach zdarzają się; ryzyko takich działań jest jednak relatywnie niewielkie.

Bogate, długie i wieloaspektowe związki szachów ze sferą polityki i ideologii zdecydowanie zasługują na osobne, kompetentne, wyczerpujące (być może wręcz monograficzne) opracowanie, którego - wedle najlepszej wiedzy piszącego te słowa - dotychczas na krajowym rynku wydawniczym się nie doczekały. Tutaj wystarczające niech będzie przypomnienie, że szachy stały się swego rodzaju orężem czy argumentem $\mathrm{w}$ rywalizacji komunistycznego i kapitalistycznego świata w okresie dwudziestowiecznej zimnej wojny (Fine, Young 2014: 91). Sukcesy - koniecznie prawomyślnych - szachistów radzieckich na olimpiadach szachowych czy w meczach o mistrzostwo świata miały dowodzić wyższości człowieka sowieckiego (a dalej: komunistycznego modelu wychowania i modelu społecznego) nad zdegenerowanym człowiekiem Zachodu (i środowiskiem, które go ukształtowało). Nadzieje wiązane z szachami były tu identyczne jak nadzieje towarzyszące sportowi w ogóle (Pasko 2012).

\footnotetext{
${ }^{14} \mathrm{~W}$ tym kontekście warto przypomnieć, że wykonywane współcześnie zaawansowane analizy statystyczne (Moul, Nye 2009) wykazują, iż podczas międzynarodowych rozgrywek szachiści radzieccy tworzyli „spółdzielnie” i byli gotowi remisować między sobą, jeśli takie rozwiązanie mogło przyczynić się do wyeliminowania zawodników spoza ZSRR i zwiększało szanse na wygraną któregokolwiek gracza radzieckiego.
}

Można spotkać się z opinią, iż szachy nie są medialne: rozgrywki są długie, nudne i nieczytelne dla osób niezaznajomionych z dyscypliną. Niemniej historia przynosi przykłady niezwykłej popularności szachów, a sama rozgrywka może być uznawana nie tyle za nudną, co za wręcz elektryzującą. Gary Alan Fine i Harvey Young (2014: 91 i nast.) przytaczają trzy momenty wyjątkowej społecznej ekscytacji szachami: nieprzerwana seria tryumfów Paula Morphy'ego nad najlepszymi zawodnikami z Europy podczas jego tournee po Starym Kontynencie z lat 1858-59; mecz Fischer-Spasski z 1972 roku oraz pojedynki Garriego Kasparowa z komputerem Deep Bule i Deeper Blue z lat 1996-97. Ze względu na przyjęte ramy czasowe analizy tu interesujące będą ostatnie dwa przypadki. Mecz z 1972 roku o mistrzostwo świata pomiędzy reprezentującym ZSRR ówczesnym mistrzem świata Borysem Spasskim a amerykańskim pretendentem Robertem Fischerem był wydarzeniem wręcz epickim, opisywanym w kategoriach pojedynku Zachodniego indywidualizmu i wytworu radzieckiej maszyny szachowej lub też amerykańskiej pomysłowości i sklerotycznej sowieckiej biurokracji (Fine, Young 2014: 93), choć zapewne każdy sympatyk szachów przyzna, że etykietki te były dla Spasskiego niezwykle krzywdzące. Sensacyjne, przygniatające zwycięstwo challengera ${ }^{15}$ przyniosło szachom wielką, acz krótkotrwałą popularność w USA, zaś działaczy szachowych w ZSRR skłoniło do intensywnych poszukiwań kandydata, który mógłby Fischerowi (możliwie szybko) odebrać tytuł czempiona (Fine, Young 2014: 93-94) ${ }^{16}$.

\footnotetext{
${ }^{15}$ Fakt, iż kapryszącego „Bobby'ego” namawiał do gry podczas rozmowy telefonicznej sam Henry Kissinger, ówczesny doradca ds. bezpieczeństwa narodowego prezydenta USA Richarda Nixona, wydaje się niezwykle znaczący z punktu widzenia rozważań o polityzacji i ideologizacji szachów.

${ }^{16}$ Selekcję i turnieje kandydatów wygrał komsomolec Anatolij Karpow. Fischer do meczu nie stanął, zaś - ideologicznie dogodnym - przeciwnikiem Karpowa (dwukrotnie przez niego pokonanym w meczach w latach 1978 i 1981) został dysydent
} 
Fischer powrócił do kraju jako bohater narodowy: zaoferowano mu zorganizowanie specjalnej parady zwycięstwa, otrzymał klucz do miasta od burmistrza Nowego Jorku i wziął udział w popularnym programie telewizyjnym Tonight Show (Fine, Young 2014: 94). Do dziś, pomimo między innymi antysemickich ekscesów, zmarły w 2008 roku Fischer jest ikoną amerykańskich szachów i postacią, o której wspomnienia w pewien sposób spajają społeczność szachistów i którą można nazwać centralną z punktu widzenia społecznej pamięci szachowego świata (Fine 2013: 400-402).

Wśród późniejszych wydarzeń szachowych największym rozgłosem cieszyły się niewątpliwie dwa mecze Kasparowa z komputerem, mające miejsce w połowie lat 90. (Smykowski 2018: 137-139). Dość powiedzieć, że drugi z meczów był obserwowany na miejscu przez 200 dziennikarzy z wiodących kanałów informacyjnych, a bilety na ostatnią partię - pierwotnie sprzedawane za 25 dolarów - były odsprzedawane z 40-krotnym przebiciem (Fine, Young 2014: 95). O popularności tych pojedynków rozstrzygały zapewne: niekwestionowana pozycja Kasparowa jako szachowego lidera, jego wcześniejsze buńczuczne zapowiedzi, iż nigdy nie zostanie pokonany przez maszynę oraz fakt, że komputer Deep Blue oraz Deeper Blue były najnowocześniejszymi produktami amerykańskiego koncernu komputerowego IBM. Podstawowe znaczenie miało jednak to, że pojedynek toczył się między człowiekiem (Kasparow w pewnym sensie reprezentował całą ludzkość) a maszyną. Zwycięstwo komputera w drugim pojedynku stało się oczywiście wiadomością dnia.

i emigrant Wiktor Korcznoj. W ten sposób narracja o wyższości szachów radzieckich - w konfrontacji już nie z tchórzliwym Amerykaninem, lecz ze zdrajcą - została ocalona.
Czy szachy ulegają mediatyzacji? Czy media wypaczają rozgrywki szachowe? Ryszard Królikowski (sędzia szachowy klasy międzynarodowej) w wypowiedzi dla portalu sport.pl (Partum 2018) wspomina pięciomiesięczny, nierozstrzygnięty pojedynek Anatolija Karpowa z Garrim Kasparowem z 1984 roku: „Mecz Kasparow-Karpow był za długi, zdążył już całemu światu spowszednieć. Na pewno zmiany [w organizacji rozgrywek o mistrzostwo świata - przyp. JRS] są determinowane walką o medialność. Kilkunastodniowy pojedynek lepiej się sprzeda $w$ mediach. $W$ dzisiejszym świecie ważne jest, aby jak najszybciej wyłonić mistrza".

Czy można natomiast mówić o komercjalizacji szachów? Zamieszczone jako motto drugiej części artykułu słowa Miguela Najdorfa o roli reklamodawców w szachach mogłyby wskazywać na to, iż szachy, szachiści i rozgrywki stały się w ostatnich latach produktem wystawionym na sprzedaż ${ }^{17}$. Za potwierdzenie tych słów niech posłużą liczne spory, w jakie wdawał się Robert Fischer z organizatorami szachowych turniejów. Przedmiotem kontrowersji bywały lokalowe warunki gry, ale przede wszystkim - kwestie pieniężne. W ostatniej chwili pod znakiem zapytania stanął rzeczony mecz z 1972 roku o mistrzostwo świata Spasski-Fischer, gdyż pretendent (sic) wysunął dodatkowe żądanie finansowe. Sytuację rozwiązał angielski bankier i milioner James Slater, pasjonat szachów, który

\footnotetext{
${ }^{17}$ Wiele wskazuje na to, że o komercjalizacji szachów można mówić od dawna. Oto co pisał Stanisław Gawlikowski (1976: 77) o negocjacjach z 1904 r. przed meczem czempiona Emanuela Laskera z pretendentem Frankiem Marshallem: „pertraktacje nie dały wyniku, mistrz świata wysunął bowiem zbyt wysokie jak na możliwości organizatorów żądania finansowe. Stawiane mu w prasie zarzuty odparował stwierdzeniem, że [...] świat szachowy, setki tysięcy szachistów, a poniekąd i następne pokolenia, które będą podziwiać partie meczowe i uczyć się na nich, powinny za to zapłacić". Wydaje się zatem, że gra szachistów od dawna wystawiona była na sprzedaż, sprzedającymi byli... sami gracze, a kupującymi - kibice, szersza publiczność, media i sponsorzy. Czyż nie tak jest w sporcie?
} 
właściwie zapłacił za grę (argumentując, że lubi szachy i chce zapewnić sobie, a także innym miłośnikom szachów, niezwykły spektakl i rozrywkę przez kilka tygodni), podwajając fundusz nagród i skłaniając Fischera do udziału w starciu (Edmonds, Eidinow 2004: 130-133; Gawlikowski 2017: 181-182).

O komercjalizacji szachów świadczy też zainteresowanie bukmacherów między innymi meczami o mistrzostwo świata. Choć szachy nie są wiodącą dyscypliną w zakładach sportowych, to jednak w przypadku wybranych imprez można typować wyniki. I tak, przykładowo, w 1993 roku angielscy bukmacherzy przyjmowali zakłady o wynik meczu między Kasparowem a pretendującym do tytułu czempiona Nigelem Shortem. Z przyjmowania zakładów wycofali się zresztą po czwartej partii, gdy zwycięstwo Kasparowa i zachowanie przez niego tytułu stało się oczywiste (Fine, Young 2014: 90). Podobnie w 2013 roku typowano zwycięzcę pojedynku Anand-Carlsen, przy czym bukmacherzy przyjmowali co najmniej 66\% szans pretendującego Magnusa Carlsena na zdobycie tytułu (Nordbye, Teigen 2014: 335).

Na koniec - z konieczności skrótowych - rozważań o komercjalizacji szachów wskażmy, że na stronie internetowej PZSzach, w osobnej zakładce „Mecenasi, sponsorzy i partnerzy", umieszczono nazwy 14 wielkich podmiotów aktualnie wspierających polskie szachy. Wydaje się, że dla określonych graczy rynkowych szachy mogą być atrakcyjnym przedmiotem sponsoringu, pozwalając na kojarzenie marki czy produktu z takimi przymiotnikami jak: „strategiczny", "genialny", ,inteligentny", „logiczny" i tak dalej. Ostatecznie firma Intel przez dłuższy czas sponsorowała rozgrywki w ramach rozłamowej organizacji Stowarzyszenie Zawodowych Szachistów (ang. Professional Chess Association - PCA), założonej w 1993 roku przez Kasparowa...

\section{Sportowe dysfunkcje w szachach - podsumowanie}

Wykonana analiza wskazuje, iż w przypadku szachów odnaleźć można wiele z tych bolączek, które są udziałem „klasycznych”, niekwestionowanych czy olimpijskich dyscyplin sportowych (kolarstwo, piłka nożna itd.). Mamy tu bowiem do czynienia z dopingiem (raczej technologicznym niż farmakologicznym) i skandalami na tym tle; mają też miejsce zdarzenia korupcyjne, choć proceder ten nie wydaje się rozpowszechniony. Można również mówić o polityzacji i ideologizacji szachów (głównie w kontekście zimnowojennym). Zarazem wiele wskazuje na to, że mediatyzacja wpływa na przebieg i reguły rozgrywek (vide: skrócenie meczów o mistrzostwo świata). Dodać do tego należy komercjalizację towarzyszącą grze królewskiej od dawna. Wszystkie wyróżnione dysfunkcje współczesnego sportu „odliczają się" zatem i w przypadku szachów, choć ich natężenie może być mniejsze $\mathrm{w}$ porównaniu z niektórymi innymi dyscyplinami.

Niejako na marginesie należy dodać, że w przypadku szachów zaobserwować można też - nieuwzględnioną $\mathrm{w}$ prezentowanej analizie - dyskryminację płciową. Jest to zagadnienie niewątpliwie zasługujące na osobne omówienie. Tu zaznaczmy jedynie, że - jak podaje portal www.worldchess.com (będący oficjalnym kanałem komunikacji FIDE) - w 2018 roku przychody najlepiej zarabiającego gracza (Magnus Carlsen) wyniosły 745211 EUR. Natomiast najlepiej zarabiająca szachistka (mistrzyni świata Wenjun Ju) uzyskała przychód na poziomie 194200 EUR i szesnastu męskich graczy zarobiło wówczas więcej od niej. Przyjęło się, że szachistki i szachiści rywalizują osobno, a świadectwem wyjątkowego zaawansowania danej zawodniczki są jej starty w turniejach adresowanych do mężczyzn (było to, jeszcze 
przed II wojną światową, udziałem Very Menchik, a współcześnie sióstr Polgar), co samo w sobie trzeba uznać za dyskryminujące. Gorsze wyniki uzyskiwane w szachach przez kobiety, w porównaniu z mężczyznami, są tłumaczone ich rzekomo słabszymi predyspozycjami do realizacji zadań wymagających intelektualnie. Niemniej można rzecz przekonująco objaśniać relatywnie niskim poziomem zainteresowania kobiet szachami, a tym samym stosunkowo małym prawdopodobieństwem znalezienia się $\mathrm{w}$ tej niewielkie populacji osób o największych zdolnościach (Bilalić i in. 2009). Dyskryminacyjna narracja - wedle której szachy kobiece są zawsze gorszą, nieudaną wersją czy naśladownictwem szachów męskich będących szachami per se - jest w przypadku szachów taka sama jak w przypadku innych dyscyplin sportowych (Jakubowska 2013: 114-115).

Podsumowując, jako że spełnione są w przypadku szachów wszystkie kryteria definicji Giulianottiego (ustrukturyzowanie, orientacja na cel, rywalizacyjny oraz ludyczny charakter) przy jednoczesnym

\section{Bibliografia}

Antonowicz Dominik, Kossakowski Radosław, Szlendak Tomasz (2011) Ostatni bastion antykonsumeryzmu? Kibice industrialni w dobie komercjalizacji sportu. „Studia Socjologiczne”, t. 202, s. 113-139.

Bilalić Merim i in. (2009) Why are (the best) women so good at chess? Participation rates and gender differences in intellectual domains. "Proceedings of the Royal Society B: Biological Sciences", vol. 1659, s. 1161-1165.

Bizoń Zdzisław (1976) Wzorce adaptacji systemu medycznego do zmian społecznych [w: Magdalena Sokołowska, Jacek Hołówka, Antonina Ostrowska, red., Socjologia a zdrowie. Warszawa: PWN, s. 107-131.

Brydż to nie sport? (2017) [dostęp 28 października 2019 r.]. Dostępny w Internecie: ‘https://www.polsatsport.pl/wiadomosc/2017-10-26/brydz-to-nie-sport/>. zaobserwowaniu - w odniesieniu do euro-amerykańskeigo kręgu kulturowego doby postprzemysłowej - wszystkich dysfunkcji właściwych sportowi, można twierdzić, że szachy są sportem i jako taki są społecznie rozpoznawane. Tym samym wydaje się, że stosowalność zaproponowanego tu podejścia została również potwierdzona. Na jego gruncie możliwe jest wykonanie analogicznych analiz, $\mathrm{w}$ odniesieniu do innych dyscyplin (niekoniecznie tylko z obszaru rywalizacji umysłowej), których sportowa tożsamość nie jest jednoznaczna.

\section{Podziękowania}

Autor chciałby serdecznie podziękować Panu Profesorowi Kazimierzowi Kowalewiczowi za lekturę pierwszej wersji artykułu i zachętę do rozwinięcia koncepcji dysfunkcjonalizmu. Autor uprzejmie dziękuje również dwóm anonimowym Recenzentom, których życzliwe uwagi oraz podpowiedzi lekturowe pozwoliły na wzbogacenie argumentacji, a w wielu miejscach - także na jej gruntowną przebudowę.

Cierpiał-Wolan Marek, Łysoń Piotr (2017) Kultura fizyczna w Polsce w latach 2015 i 2016. Warszawa, Rzeszów: Główny Urząd Statystyczny.

Coakley Jay (2001) Sport in Society: Issues and Controversies. New York: McGraw Hill.

Coubertin de Pierre (1989) Textes choisis. Zurich, Hildesheim, New York: Weidmann, t. 2.

Demel Maciej, Skład Alicja (1974) Teoria wychowania fizycznego. Warszawa: PWN.

Dudek Dobiesław (brw) Krytyczne tezy do naukowych badań nad sportem [dostęp 28 października 2019 r.]. Dostępny w Internecie: 
http://wtir.awf.krakow.pl/pdf/rozne/publik_pracownikow/dobieslaw_dudek/krytyczne_tezy.pdfı.

Dziubiński Zbigniew (2003) Wprowadzenie [w:] Zbigniew Dziubiński, red., Społeczny wymiar sportu. Warszawa: Salezjańska Organizacja Sportowa RP, s. 13-17.

Dziubiński Zbigniew (2011a) Olimpizm a nowoczesność [w:] Zbigniew Dziubiński, Zbigniew Krawczyk, red., Socjologia kultury fizycznej. Warszawa: Wydawnictwo Akademii Wychowania Fizycznego im. J. Piłsudskiego, s. 121-137.

Dziubiński Zbigniew (2011b) Dewiacje w sporcie wyczynowym [w:] Zbigniew Dziubiński, Zbigniew Krawczyk, red., Socjologia kultury fizycznej. Warszawa: Wydawnictwo Akademii Wychowania Fizycznego im. J. Piłsudskiego, s. 444-462.

Dziubiński Zbigniew (2015) Polityka i sport: antynomie i konwergencje [w:] Zbigniew Dziubiński, Kazimierz W. Jankowski, red., Kultura fizyczna a polityka. Warszawa: Salezjańska Organizacja Sportowa RP, s. 15-43.

Edmonds David, Eidinow John (2004) Bobby Fischer Goes to War. London: Faber \& Farber.

Fine Gary Alan (2013) Sticky Cultures: Memory Publics and Communal Pasts in Competitive Chess. "Cultural Sociology", vol. 7, s. 395-414.

Fine Gary Alan, Young Harvey (2014) Still Thrills: The Drama of Chess. “The Drama Review”, vol. 58, s. 87-98.

Franke Andreas G. i in. (2017) Methylphenidate, modafinil, and caffeine for cognitive enhancement in chess: A double-blind, randomised controlled trial. "European Neuropsychopharmacology", vol. 27, s. $248-260$.

Gajewski Jacek (2012) Szachy z perspektywy definicji sportu. "IDO Movement for Culture. Journal of Martial Arts Anthropology", t. 12, s. 6-10.

Gawlikowski Stanisław (1976) Walka o tron szachowy. Warszawa: Sport i Turystyka.

Gawlikowski Stefan (2017) Bobby Fischer. Obsesje geniusza. Warszawa: The Facto.

Giulianotti Richard (2005) Prologue [w:] Richard Giulianotti, ed., Sport: A Critical Sociology. Cambridge: Polity Press, s. xi-xx.

Giżycki Jerzy (1984) Z szachami przez wieki i kraje. Warszawa: Sport i Turystyka.
Golf Sighart (2015) Doping for Chess Performance. "Sports Medicine \& Doping Studies", vol. 5, s. 1-16.

Gołata Krzysztof (2011) Kształtowanie wizerunku sponsora - zagrożenia wizerunkowe w polskiej piłce nożnej. „Zeszyty Naukowe Uniwersytetu Ekonomicznego w Poznaniu", t. 197, s. 93-103.

Hajduk Edward, Hajduk Fabian (2013) Szkice z socjologii sportu. Poznań: Wydawnictwo Wyższej Szkoły Bezpieczeństwa.

ICSS (2014) Protecting the Integrity of Sport Competition. The Last Bet for Modern Sport [dostęp 28 października 2019 r.]. Dostępny w Internecie: http://theicss.org/2019/03/12/icss-protecting-theintegrity-of-sport-competition-the-last-bet-for-modern-sport/s.

Jakubowska Honorata (2013) Płeć (w) fizjologii sportu. „Kultura Współczesna", t. 78, s. 105-117.

Jankowski Krzysztof (2011) Procesy komercjalizacji kultury fizycznej [w:] Zbigniew Dziubiński, Zbigniew Krawczyk, red., Socjologia kultury fizycznej. Warszawa: Wydawnictwo Akademii Wychowania Fizycznego im. J. Piłsudskiego, s. 387-403.

Kałamacka Ewa (2000) Sport XXI wieku epigonem antyku [w:] Zbigniew Dziubiński, red., Sport na przełomie tysiacleci: szanse i nadzieje. Warszawa: Salezjańska Organizacja Sportowa RP, s. 151-157.

Kobiela Filip (2015) Z ontologii gry w szachy. Uwagi na kanwie rozważań Romana Ingardena. „Kwartalnik Filozoficzny”, t. 43, s. 61-78.

Kobiela Filip (2018) Should chess and other mind sports be regarded as sports? "Journal of the Philosophy of Sport", vol. 45, s. 279-295.

Kopecka-Piech Katarzyna (2017) Media [w:] Honorata Jakubowska, Przemysław Nosal, red., Socjologia sportu. Warszawa: Wydawnictwo Naukowe PWN, s. 75-85.

Kosiewicz Jerzy (2001) Wspótczesny olimpizm w świetle wartości społecznych [w:] Zbigniew Dziubiński, red., Aksjologia sportu. Warszawa: Salezjańska Organizacja Sportowa RP, s. 189-195.

Kossakowski Radosław (2017) Kibice [w:] Honorata Jakubowska, Przemysław Nosal, red., Socjologia sportu. Warszawa: Wydawnictwo Naukowe PWN, s. 47-59.

Kowalczyk Stanisław (2009) Ku (re)humanizacji sportu w społeczeństwie nowoczesnym [w:] Zbigniew Dziubiński, Kazimierz W. Jankowski, red., Kultura fizyczna w społeczeństwie nowoczesnym. Warszawa: Salezjańska Organizacja Sportowa RP, s. 51-57. 
Krawczyk Zbigniew (2000) Sport w zmieniajacym się społeczeństwie. Warszawa: Wydawnictwo Akademii Wychowania Fizycznego im. J. Piłsudskiego.

Krawczyk Zbigniew (2003) Sport jako zwierciadło współczesnego społeczeństwa [w:] Zbigniew Dziubiński, red., Społeczny wymiar sportu. Warszawa: Salezjańska Organizacja Sportowa RP, s. $161-167$.

Kubiak Anna (2013) Działania antykorupcyjne - wybrane przykłady. „Acta Universitatis Lodziensis - Folia Oeconomica”, t. 288, s. 45-57.

Lenartowicz Michał, Mosz Jakub (2018) Stadiony i widowiska. Społeczne przestrzenie sportu. Warszawa: Scholar.

Leszczyńska Aleksandra (2013) Etyczne i społeczne kontrowersje wokół współczesnego sportu profesjonalnego. „Humanizacja Pracy", t. 272, s. 43-57.

Leszczyńska Aleksandra (2017) Doping [w:] Honorata Jakubowska, Przemysław Nosal, red., Socjologia sportu. Warszawa: Wydawnictwo Naukowe PWN, s. 11-24.

Lipoński Wojciech (1987) Humanistyczna encyklopedia sportu. Warszawa: Sport i Turystyka.

Lipoński Wojciech (2009) Mocowanie duszy z ciałem. O humanistyczny wymiar sportu [w:] Zbigniew Dziubiński, Kazimierz W. Jankowski, red., Kultura fizyczna w społeczeństwie nowoczesnym. Warszawa: Salezjańska Organizacja Sportowa RP, s. 34-50.

Litmanowicz Władysław, Giżycki Jerzy (1986) Szachy od A do Z. Warszawa: Sport i Turystyka.

Łuczak Maciej (2018) Oszustwo dopingowe w sporcie wyczynowym wśród kobiet w latach 1950-2017. „Rozprawy Naukowe Akademii Wychowania Fizycznego we Wrocławiu", t. 60, s. 118-134.

Manicka Zuzanna, Strzelecki Wojciech (2010) Świadomość niepożądanych efektów zdrowotnych stosowania dopingu przez sportowców wśród uczniów szkót średnich. „Pielęgniarstwo Polskie”, t. 34, s. 173-180.

Merton Robert K. (2002) Teoria socjologiczna i struktura społeczna. Warszawa: Wydawnictwo Naukowe PWN.

Mihailov Emilian, Savulescu Julian (2018) Social Policy and Cognitive Enhancement: Lessons from Chess. “Neuroethics”, vol. 11, s. 115-127.

Moul Charles C., Nye John V. C. (2009) Did the Soviets collude? A statistical analysis of championship chess 1940-1978. "Journal of Economic Behavior \& Organization", vol. 70, s. 10-21.
Nordbye Gro H.H., Teigen Karl H. (2014) Responsibility judgments of wins and losses in the 2013 chess championship. "Judgment and Decision Making", vol. 9, s. 335-348.

Nosal Przemysław (2015) Społeczne ujęcie sportu. (Trudne) definiowanie zjawiska i jego dyskurs. „Przegląd Socjologii Jakościowej”, t. 11, s. 16-38.

Openfield (2018) Zjawisko korupcji w środowisku sportowym. Analiza w oparciu o badania empiryczne [dostęp 28 października 2019 r.]. Dostępny w Internecie: 〈https://www.gov.pl/documents/292437/436728/Zjawisko_korupcji_-_Raport.pdf/ad2bffcf-97e8-c169-686d-b36cc6a01c46).

Partum Antoni (2018) Czy szachy czeka rewolucja? „Szachy losowe sa coraz popularniejsze i moga kiedyś wyprzeć tradycyjne rozgrywki" - rozmowa z Ryszardem Królikowkim [dostęp 28 października 2019 r.]. Dostępny w Internecie: ‘http://www.sport.pl/ inne/7,64998,24246608,czy-szachy-przejda-rewolucje-szachy-losowe-sa-coraz-popularniejsze.html».

Pasko Artur (2012) Społeczno-polityczne aspekty sportu w ZSRR i krajach bloku socjalistycznego do 1989 r. „Prace Naukowe Akademii im. Jana Długosza w Częstochowie. Kultura Fizyczna”, t. 11, s. 115-130.

Pawlak Zbigniew, Smoleń Andrzej (2010) Dylematy etyczne rozwoju sportu zawodowego. "Annales. Etyka w życiu gospodarczym", t. 13, s. 105-114.

Petroczi Andrea (2009) Introduction. The Dark Side of Sport: Challenges for Managers in the Twenty-first Century. „European Sport Management Quarterly", vol. 9, s. 349-352.

Pospiszyl Irena (2014) Patologie społeczne. Warszawa: Wydawnictwo Naukowe PWN.

Prost Frédéric (2012) On the impact of information technologies on society: an historical perspective through the game of chess. "EPiC Series", vol. 10, s. 1-12.

Schulenkorf Nico, Frawley Stephen, red., (2016) Critical Issues in Global Sport Management. London: Routledge.

Smykowski Mikołaj (2018) Szachy - (nie)ludzka gra. Ludzie, maszyny i antycypacje przyszłości. „Kultura Współczesna”, t. 101, s. 132-142.

Sobotko Ewelina (2017) Perspektywy rozwoju rynku zakładów bukmacherskich w Polsce. "Zeszyty Naukowe Wyższej Szkoły Ekonomiczno-Społecznej w Ostrołęce”, t. 25, s. 96-107.

Sokołowska Magdalena (1972) Dysfunkcjonalności instytucji służby zdrowia. "Studia Socjologiczne”, nr 4, s. 135-161. 
Stańczuk Krzysztof (1995) Dewiacje w sporcie woyczynowym [w:] Zbigniew Krawczyk, red., Socjologia kultury fizycznej. Warszawa: Wydawnictwo Akademii Wychowania Fizycznego im. J. Piłsudskiego, s. 275-286.

Świerczyński Marek Jarosław (2017) Mediatyzacja sportu. Zmiany w medialnym przekazie igrzysk olimpijskich. "Zeszyty Naukowe KUL”, t. 60, s. 197-211.

Suits Bernard (2007) The Elements of Sport [w:] William J. Morgan, ed., Ethics in Sport. Champaign, Illinois: Human Kinetics, s. 9-19.

Ustawa z dnia 25 czerwca 2010 r. o sporcie (Dz. U. 2010 Nr 127 poz. 857).

Ustawa z dnia 20 lipca 2017 r. o zmianie ustawy o sporcie oraz ustawy o ujawnianiu informacji o dokumentach organów bezpieczeństwa państwa z lat 1944-1990 oraz treści tych dokumentów (Dz.U. 2017 poz. 1600).

Waśkowski Zygmunt (2011) Integracyjna rola sportu we współczesnym świecie. "Zeszyty Naukowe Uniwersytetu Szczecińskiego. Ekonomiczne Problemy Usług", t. 78, s. 25-34.
Weiss Paul (1969) Sport. A Philosophical Inquiry. Carbondale: Southern Illinois University Press.

Włoch Renata (2017) Wielkie imprezy sportowe [w:] Honorata Jakubowska, Przemysław Nosal, red., Socjologia sportu. Warszawa: Wydawnictwo Naukowe PWN, s. 243-251.

Woźniak Wojciech (2011) Najlepsi na świecie? O fenomenie siatkówki i jej kibiców w Polsce [w:] Łukasz Rogowski, Radosław Skrobacki, red., Społeczne zmagania ze sportem. Poznań: Wydawnictwo Uniwersytetu im. Adama Mickiewicza, s. 289-309.

Woźniak Wojciech (2017) Polityka [w:] Honorata Jakubowska, Przemysław Nosal, red., Socjologia sportu. Warszawa: Wydawnictwo Naukowe PWN, s. 147-163.

www.msit.gov.pl [strona internetowa Ministerstwa Sportu i Turystyki].

www.worldchess.com [Official FIDE Broadcasting].

\title{
Cytowanie
}

Stempień Jakub Ryszard (2020) Dysfunkcjonalizm metodologiczny - nowa propozycja analityczna w socjologii sportu i jej zastosowanie na przykładzie szachów. „Przegląd Socjologii Jakościowej”, t. 16, nr 1, s. 162-185 [dostęp dzień, miesiąc, rok]. Dostępny w Internecie: 〈www.przegladsocjologiijakosciowej.org〉. DOI: http://dx.doi.org/10.18778/1733-8069.16.1.10

\section{Methodological Dysfunctionalism: A New Analytical Approach in the Sociology of Sport and Its Exemplary Implementation Based on the Example of Chess}

\begin{abstract}
The article investigates the problem of the empirical use of some definitions of sport, formulated on the grounds of the so-called contextual approach and structured contextualism (typology of P. Nosal). A question about how to research the social recognition(crucial within these definitions) of a particular activity as a sports activity is problematic. The suggested authorial solution is called methodological dysfunctionalism and assumes that negative phenomena (dysfunctions) within sport may be treated as indexes of a particular state of social awareness. Five dysfunctions are covered in the analysis, following Merton's understanding of this notion. These include: doping, corruption, politicization, commercialization, and mediatization. In the second part of the paper, the presented approach is tested based on the example of chess (the applied definition of sport is the one introduced by R. Giulianotti). The collected data shows that when investigating chess, one can observe many of the negative phenomena that are generally considered to be the 'dark side' of sport. Taking into account that all of the criteria of Giulianotti's definition were fulfilled as well as the presence of typical sports dysfunctions was confirmed, it is reasonable - and congruent with methodological dysfunctionalism - to conclude that chess should be considered a sport.
\end{abstract}

Keywords: sport, sociology of sport, dysfunctions within sport, methodological dysfunctionalism, chess 